\title{
Mercury transformation and speciation in flue gases from anthropogenic emission sources: a critical review
}

\author{
Lei Zhang ${ }^{1}$, Shuxiao Wang ${ }^{1,2}$, Qingru Wu ${ }^{1}$, Fengyang Wang ${ }^{1}$, Che-Jen Lin ${ }^{3}$, Leiming Zhang ${ }^{4}$, Mulin Hui ${ }^{1}$, \\ Mei Yang ${ }^{1}$, Haitao $\mathrm{Su}^{1}$, and Jiming Hao ${ }^{1,2}$ \\ ${ }^{1}$ State Key Joint Laboratory of Environment Simulation and Pollution Control, School of Environment, Tsinghua University, \\ Beijing 100084, China \\ ${ }^{2}$ State Environmental Protection Key Laboratory of Sources and Control of Air Pollution Complex, Beijing 100084, China \\ ${ }^{3}$ Center for Advances in Water and Air Quality, Lamar University, Beaumont, TX, USA \\ ${ }^{4}$ Air Quality Research Division, Science and Technology Branch, Environment Canada, Toronto, Canada \\ Correspondence to: S. X. Wang (shxwang@tsinghua.edu.cn)
}

Received: 31 October 2015 - Published in Atmos. Chem. Phys. Discuss.: 24 November 2015

Revised: 12 February 2016 - Accepted: 13 February 2016 - Published: 29 February 2016

\begin{abstract}
Mercury transformation mechanisms and speciation profiles are reviewed for mercury formed in and released from flue gases of coal-fired boilers, non-ferrous metal smelters, cement plants, iron and steel plants, waste incinerators, biomass burning and so on. Mercury in coal, ores, and other raw materials is released to flue gases in the form of $\mathrm{Hg}^{0}$ during combustion or smelting in boilers, kilns or furnaces. Decreasing temperature from over $800^{\circ} \mathrm{C}$ to below $300^{\circ} \mathrm{C}$ in flue gases leaving boilers, kilns or furnaces promotes homogeneous and heterogeneous oxidation of $\mathrm{Hg}^{0}$ to gaseous divalent mercury $\left(\mathrm{Hg}^{2+}\right)$, with a portion of $\mathrm{Hg}^{2+}$ adsorbed onto fly ash to form particulate-bound mercury $\left(\mathrm{Hg}_{\mathrm{p}}\right)$. Halogen is the primary oxidizer for $\mathrm{Hg}^{0}$ in flue gases, and active components (e.g., $\mathrm{TiO}_{2}, \mathrm{Fe}_{2} \mathrm{O}_{3}$, etc.) on fly ash promote heterogeneous oxidation and adsorption processes. In addition to mercury removal, mercury transformation also occurs when passing through air pollution control devices (APCDs), affecting the mercury speciation in flue gases. In coal-fired power plants, selective catalytic reduction (SCR) system promotes mercury oxidation by $34-85 \%$, electrostatic precipitator (ESP) and fabric filter (FF) remove over $99 \%$ of $\mathrm{Hg}_{\mathrm{p}}$, and wet flue gas desulfurization system (WFGD) captures $60-95 \%$ of $\mathrm{Hg}^{2+}$. In non-ferrous metal smelters, most $\mathrm{Hg}^{0}$ is converted to $\mathrm{Hg}^{2+}$ and removed in acid plants (APs). For cement clinker production, mercury cycling and operational conditions promote heterogeneous mercury oxidation and adsorption. The mercury speciation profiles in flue gases emitted to the atmosphere are determined by trans-
\end{abstract}

formation mechanisms and mercury removal efficiencies by various APCDs. For all the sectors reviewed in this study, $\mathrm{Hg}_{\mathrm{p}}$ accounts for less than $5 \%$ in flue gases. In China, mercury emission has a higher $\mathrm{Hg}^{0}$ fraction $(66-82 \%$ of total mercury) in flue gases from coal combustion, in contrast to a greater $\mathrm{Hg}^{2+}$ fraction (29-90\%) from non-ferrous metal smelting, cement and iron and/or steel production. The higher $\mathrm{Hg}^{2+}$ fractions shown here than previous estimates may imply stronger local environmental impacts than previously thought, caused by mercury emissions in East Asia. Future research should focus on determining mercury speciation in flue gases from iron and steel plants, waste incineration and biomass burning, and on elucidating the mechanisms of mercury oxidation and adsorption in flue gases.

\section{Introduction}

Atmospheric mercury is one of the key focuses in the global environmental issues in recent years owing to its toxicity, persistence, and long-range transportability. The international treaty on mercury, the Minamata Convention, was adopted worldwide in October 2013 aiming to reduce mercury release into the immediate environments. Coal combustion, cement clinker production, and primary production of ferrous and non-ferrous metals are predominant sources of global anthropogenic mercury emission (UNEP, 2013a). Aside from coal-fired power plants, coal-fired industrial boil- 
ers, cement clinker production facilities, and smelting and roasting processes used in the production of non-ferrous metals (lead, zinc, copper and industrial gold), waste incineration facilities, in terms of their rapid growth, are also on the list of key point sources in Annex D for Article 8 of the Minamata Convention (UNEP, 2013b).

Mercury has three major chemical forms: gaseous elemental mercury $\left(\mathrm{Hg}^{0}\right)$, gaseous oxidized (or reactive) mercury $\left(\mathrm{Hg}^{2+}\right)$ and particulate-bound mercury $\left(\mathrm{Hg}_{\mathrm{p}}\right) \cdot \mathrm{Hg}^{0}$, the most stable form, accounts for over $90 \%$ of the total mercury in the atmosphere. Its residence time is estimated to be several months to over 1 year (Schroeder and Munthe, 1998; Lindberg et al., 2007; Fu et al., 2012), but could be as short as hours to weeks under specific environmental conditions (Gustin et al., 2008). $\mathrm{Hg}^{2+}$ has high water solubility and thus can be easily scavenged into droplets and adsorbed to surfaces followed by wet and dry deposition. The short residence time (hours to days) of $\mathrm{Hg}^{2+}$ leads to more prominent local environmental impacts. $\mathrm{Hg}_{\mathrm{p}}$ has a residence time of hours to weeks, and mercury on finer particles can be transported for long distances (Schroeder and Munthe, 1998). $\mathrm{Hg}^{2+}$ and $\mathrm{Hg}_{\mathrm{p}}$ are also referred to as reactive mercury (RM) due to their high surface reactivity (Rutter and Schauer, 2007). Mercury speciation profiles in the exhausted flue gases from key sources determine the behavior of atmospheric mercury in the ambient air, while the profiles in the pipeline flue gases are crucial to mercury emission controls.

Different emission sources have different mercury speciation profiles. Even for the same emission category, the profile varies significantly when different combinations of air pollution control devices (APCDs) are applied or different types of fuels or raw materials are used. Different countries or regions have distinguished mercury speciation profiles for similar emission sources because of APCD preferences and fuel (or raw material) properties. The profiles can vary with time as advanced air pollution control technologies are implemented. Inventory experts tend to use more localized and up-to-date profiles from on-site measurements of mercury emission sources. Walcek et al. (2003) employed three sets of profiles respectively for fuel combustion, waste incineration and other manufacturing processes, and found the overall relative emission proportions (REPs) among $\mathrm{Hg}^{0}: \mathrm{Hg}^{2+}: \mathrm{Hg}_{\mathrm{p}}$ species for the 1996 inventory of eastern North America to be $47: 35: 18$. Streets et al. (2005) accomplished a more detailed profile list for different source categories with profiles under different APCDs for coal combustion, and obtained the overall REPs for China in 1999 which were $56: 32: 12$. Pacyna et al. (2006) developed the 2000 mercury emission inventory for Europe and evaluated the overall REPs to be 61 : $32: 7$. The REPs for anthropogenic mercury emissions from Korea in 2007 were estimated to be $64: 29: 7$ (Kim et al., 2010a), and those for the 2006 inventory of Australia were $77: 17: 6$ (Nelson et al., 2012). Our recent study updated the anthropogenic mercury emission inventory of China to the calendar year 2010 based on an abundant database of field measurements, and the REPs of the overall mercury speciation profile were $58: 39: 3$ (Zhang et al., 2015). Although the ratio of $\mathrm{Hg}^{0}$ to $\mathrm{Hg}^{2+}$ seems to be close to the results from Streets et al. (2005), the sectoral profiles have changed significantly because of the implementation of APCDs in key sources in China. Results from on-site measurements in Chinese power plants, non-ferrous metal smelters and cement plants have substantially improved the speciation profiles.

Mercury speciation profiles of major emission sources in the world have remarkable influences on the assessment of long-range transport of atmospheric mercury. This paper provides a critical review of mercury speciation in flue gases from major anthropogenic emission sources, and elaborates the process of initial mercury release in boilers, kilns or furnaces to its transformation in the flue gases across APCDs. Key factors during the emission process for each source are identified for the enhancement of existing control technologies. Profiles of mercury speciation in different countries and regions are compared by sectors to assess their local and regional environmental impacts.

\section{Mercury speciation and transformation in flue gases from coal combustion}

\subsection{Mercury speciation in flue gas from coal combustion}

Nearly all mercury in coal is released into the flue gas in the form of $\mathrm{Hg}^{0}$ during combustion over $1000^{\circ} \mathrm{C}$. With the decrease of flue gas temperature out of the boiler, a portion of $\mathrm{Hg}^{0}$ is oxidized to $\mathrm{Hg}^{2+}$ mainly by active atomic $\mathrm{Cl}$ generated from $\mathrm{HCl}, \mathrm{Cl}_{2}$ or $\mathrm{HOCl}$ (Senior et al., 2000). Niksa et al. (2001) discovered that the cycling of atomic $\mathrm{Cl}$ is the dominant mechanism of $\mathrm{Hg}^{0}$ oxidation. This process, including homogeneous and heterogeneous reactions, is driven by thermodynamic equilibrium, but restricted by reaction kinetics (Widmer et al., 2000). Based on the results from benchscale experiments, L. Zhang et al. (2013a) found that lower total mercury concentration and higher chlorine concentration in flue gas lead to higher $\mathrm{Hg}^{0}$ oxidation rate. The results from Sterling et al. (2004) showed that $\mathrm{SO}_{2}$ and $\mathrm{NO}$ in flue gas inhibit the oxidation of $\mathrm{Hg}^{0}$. The homogeneous reaction mechanism usually underestimates the oxidation rate because heterogeneous reactions on fly ash play a more important role under low temperatures $\left(100\right.$ to $\left.300^{\circ} \mathrm{C}\right)$. Heterogeneous processes not only accelerate the oxidation of $\mathrm{Hg}^{0}$ but also contribute to the adsorption of $\mathrm{Hg}^{2+}$ onto fly ash to form $\mathrm{Hg}_{\mathrm{p}}$. Bhardwaj et al. (2009) found that specific surface area (SSA), loss on ignition (LOI) and average particle size positively correlated with both the $\mathrm{Hg}^{0}$ oxidation and the $\mathrm{Hg}^{2+}$ adsorption. Inorganic components such as $\mathrm{CuO}, \mathrm{TiO}_{2}$, and $\mathrm{Fe}_{2} \mathrm{O}_{3}$ also have significant impacts on the mercury oxidation and adsorption processes (Dunham et al., 2003; Norton et al., 2003; López-Antón et al., 2007). 
According to 30 previous on-site measurements in coalfired power plants and industrial boilers (Kellie et al., 2004; Duan et al., 2005; Lee et al., 2006; Zhou et al., 2006; Chen et al., 2007; Yang et al., 2007; Chen et al., 2008; Wang et al., 2008; Zhou et al., 2008; Kim et al., 2010b; Wang et al., 2010a; Zhang et al., 2012a; L. Zhang et al., 2013a), mercury speciation after the boiler and before APCDs is mainly determined by coal properties, specifically chlorine, mercury, and ash contents in coal. Chlorine and mercury contents have the most significant impacts on the percentage of $\mathrm{Hg}^{2+}$ in total mercury, while mercury and ash contents highly influence the proportion of $\mathrm{Hg}_{\mathrm{p}}$ in total mercury in flue gas. The proportions of $\mathrm{Hg}^{0}, \mathrm{Hg}^{2+}$ and $\mathrm{Hg}_{\mathrm{p}}$ in the flue gas released from a pulverized-coal (PC) boiler, averaged 56, 34 and 10\%, respectively. However, $\mathrm{Hg}^{2+}$ proportion ranged from 5 to $82 \%$ while $\mathrm{Hg}_{\mathrm{p}}$ proportion ranged from 1 to $28 \%$. Besides the coal properties, the boiler type also affects mercury speciation in flue gas. A circulating fluidized bed (CFB) boiler can generate as high as $65 \%$ of $\mathrm{Hg}_{\mathrm{p}}$ in flue gas due to more sufficient contact between gaseous phase mercury and fly ash inside the boiler (Zhang, 2012).

\subsection{Mercury transformation across APCDs for coal combustion}

\subsubsection{Mercury transformation during selective catalytic reduction $(\mathrm{SCR})$}

Figure 1 shows mercury transformation and removal processes across APCDs in coal-fired power plants. The first APCD after the boiler could be the SCR system if applied for $\mathrm{NO}_{x}$ control. The operation temperature in an SCR is typically $300-400^{\circ} \mathrm{C}$. SCR catalysts, usually composed of $\mathrm{V}_{2} \mathrm{O}_{5}, \mathrm{WO}_{3}$, and $\mathrm{TiO}_{2}$, significantly promote the $\mathrm{Hg}^{0}$ oxidation process and increase $\mathrm{Hg}^{2+}$ level for downstream removal in $\mathrm{PM}$ and $\mathrm{SO}_{2}$ control devices (Niksa and Fujiwara, 2005). Laboratory-scale studies (Lee et al., 2003; Bock et al., 2003) showed that $\mathrm{Hg}^{0}$ oxidant inside SCR is the atomic $\mathrm{Cl}$. The $\mathrm{Hg}-\mathrm{Cl}$ redox chemistry and the $\mathrm{NO}-\mathrm{NH}_{3}$ redox chemistry occur simultaneously on the active sites of SCR catalyst (L. Zhang et al., 2013b). Therefore, the reaction system in SCR is complicated and influenced by a number of factors. Machalek et al. (2003) pulled subbituminous-derived flue gas into a pilot-scale SCR system and found that the $\mathrm{Hg}^{0}$ oxidation extent decreased from 40 to $5 \%$ when the space velocity (SV) of SCR was increased from 3000 to $7800 \mathrm{~h}^{-1}$. The influence of $\mathrm{NH}_{3}$ is more controversial. The study of Machalek et al. (2003) found that $\mathrm{NH}_{3}$ inhibits the oxidation of $\mathrm{Hg}^{0}$ inside SCR. Niksa and Fujiwara (2005) theoretically calculated this process and addressed the inhibition mechanism by $\mathrm{NH}_{3}$ competing with atomic $\mathrm{Cl}$ on active sites. However, on-site measurements in three coal-fired power plants showed the opposite results, that is, the increase of $\mathrm{NH}_{3}$ injection rate promotes $\mathrm{Hg}^{0}$ oxidation (L. Zhang et al., 2013b). Possible chemical mechanism was proposed for the observed oxida- tion, but requires further investigation. The concentrations of $\mathrm{NO}, \mathrm{SO}_{2}$ and total mercury and the type and on-duty time of the SCR catalyst also affect the heterogeneous oxidation processes inside SCR (Winberg et al., 2004; Niksa and Fujiwara, 2005; L. Zhang et al., 2013b). Field tests in coal-fired power plants showed an average $\mathrm{Hg}^{0}$ oxidation rate of $71 \%$ with a range of 34-85\% (Chen et al., 2008; Zhang, 2012; L. Zhang et al., 2013b).

\subsubsection{Mercury transformation in electrostatic precipitator (ESP)}

Due to its high PM removal efficiency and relatively low cost, ESP is the most widely used PM controller in coalfired power plants. Over $99 \%$ of $\mathrm{Hg}_{\mathrm{p}}$ is removed inside ESP (Wang et al., 2010a). A small portion of $\mathrm{Hg}^{2+}$ can also be adsorbed onto fly ash and removed by ESP. The $\mathrm{Hg}^{2+}$ capture rate is determined by the unburned carbon (UBC) on fly ash (Senior and Johnson, 2005). The total mercury removal efficiency of ESP is usually in the range of $20-40 \%$ at $\sim 5 \%$ UBC content of fly ash. Besides the UBC, the surface property, size, porous structure, and mineral composition of fly ash affect the mercury capture rate of ESP as well (Lu et al., 2007). When coal with high chlorine content is burned, more UBC is generated on fly ash and more $\mathrm{Hg}^{2+}$ and $\mathrm{Hg}_{\mathrm{p}}$ are formed in flue gas, which in turn increase the mercury capture rate inside ESP. Improvement of ESP for capturing fine particles (e.g., adding electric fields inside ESP) will also increase mercury removal efficiency. Inter-conversion between $\mathrm{Hg}^{0}$ and $\mathrm{Hg}^{2+}$ occurs inside ESP (Zhang, 2012). The charging anode of ESP can neutralize $\mathrm{Hg}^{2+}$ and convert it to $\mathrm{Hg}^{0}$, while $\mathrm{Hg}^{0}$ in flue gas continues to be oxidized to $\mathrm{Hg}^{2+}$ via heterogeneous reactions in ESP under temperatures of 150$200{ }^{\circ} \mathrm{C}$. Therefore, $\mathrm{Hg}^{0}$ concentration can either increase or decrease inside ESP depending on the processes interplay. On-site measurements showed an average mercury removal efficiency of $29 \%$ for ESP with a large range of 1-74\% (Goodarzi, 2004; Guo et al., 2004; Kellie et al., 2004; Tang, 2004; Duan et al., 2005; Lee et al., 2006; Chen et al., 2007; Yang et al., 2007; Wang et al., 2008; Zhou et al., 2008; Kim et al., 2010b; Shah et al., 2010; ICR, 2010; Wang et al., 2010a; Zhang et al., 2012a). Nevertheless, ESP installed after a CFB boiler can achieve an average of $74 \%$ mercury removal due to the high $\mathrm{Hg}_{\mathrm{p}}$ proportion in flue gas (Chen et al., 2007; ICR, 2010; Zhang, 2012).

\subsubsection{Mercury transformation in fabric filter (FF)}

A higher PM removal efficiency can be achieved by FF than by ESP, especially for fine particles. FF is increasingly applied in coal-fired power plants and industrial boilers in the need of fine particle $\left(\mathrm{PM}_{2.5}\right.$ or $\left.\mathrm{PM}_{1}\right)$ control. FF has mercury removal efficiencies of 9-92\% with an average of $67 \%$ (Chen et al., 2007; Shah et al., 2008; Wang et al., 2009; ICR, 2010). Besides $\mathrm{Hg}_{\mathrm{p}}$, FF can also remove over $50 \%$ of $\mathrm{Hg}^{2+}$. 


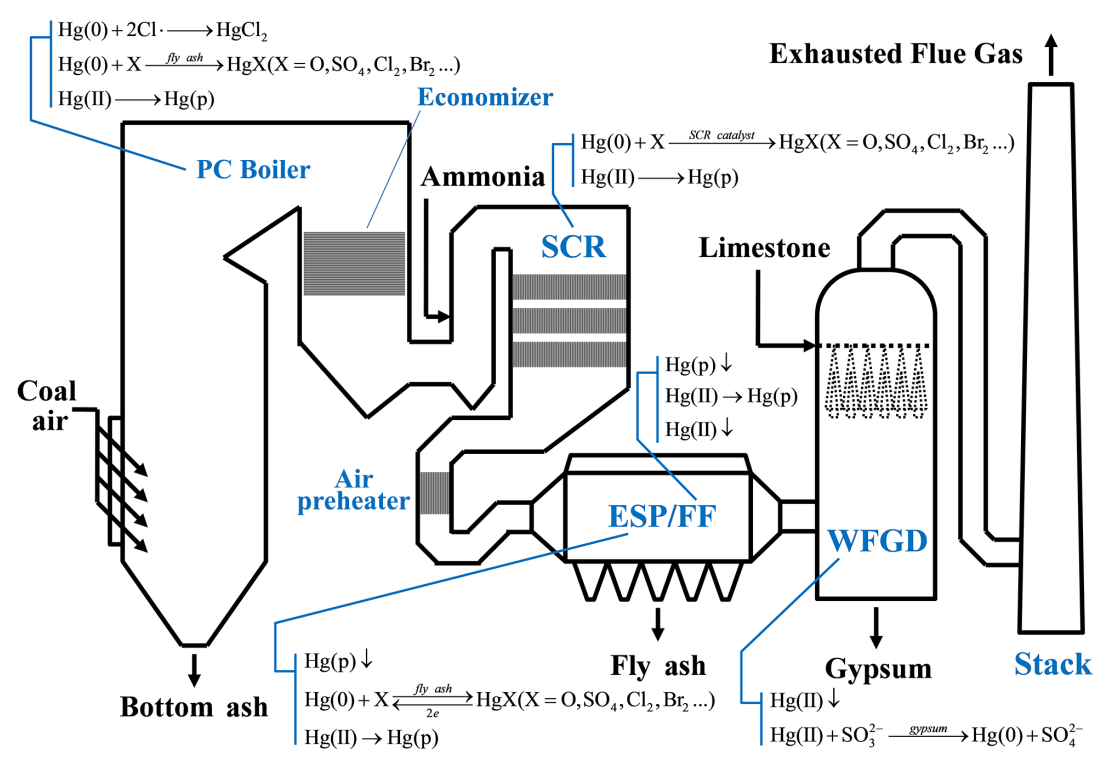

Figure 1. Mercury transformation and removal across APCDs in coal-fired power plants.

During the filtration, contact between flue gas and the particles on the cake layer promotes adsorption of $\mathrm{Hg}^{2+}$ onto fly ash (Zhang, 2012). The properties of fly ash have the most significant impact on $\mathrm{Hg}^{2+}$ adsorption. The dust cake layer can also facilitate the oxidation of $\mathrm{Hg}^{0}$ (Wang et al., 2016a).

Some plants apply ESP-FF hybrid precipitator to improve the fine particle removal efficiency. Limited studies suggested an overall mercury removal rate of $39 \%$ in ESP-FF hybrid precipitator (S. X. Wang et al., 2014).

\subsubsection{Mercury transformation during wet flue gas desulfurization (WFGD)}

WFGD is the most widely used APCD for $\mathrm{SO}_{2}$ control in coal-fired power plants. During sulfur (mainly $\mathrm{SO}_{2}$ ) scrubbing process, $\mathrm{Hg}^{2+}$ is also removed in WFGD. The average mercury removal efficiency of WFGD is $64 \%$, ranging from 56 to $88 \%$ (Lee et al., 2006; Chen et al., 2007; Kim et al., 2010b; Wang et al., 2010a). Insoluble $\mathrm{Hg}^{0}$ passes through WFGD without being captured. Chemical reduction of the dissolved $\mathrm{Hg}^{2+}$ reduces total mercury removal efficiency in WFGD due to re-volatilization of $\mathrm{Hg}^{0}$ (Wo et al., 2009; Ochoa-González et al., 2013). Flue gas and slurry composition, operating temperature, limestone injection rate, and slurry $\mathrm{pH}$ are the key factors affecting the re-volatilization of $\mathrm{Hg}^{0}$ (Acuña-Caro et al., 2009; Ochoa-González et al., 2012; Schuetze et al., 2012). WFGD is the crucial step in the co-benefit mercury control technologies in coal-fired power plants. The applications of high-chlorine coal, SCR and halogen addition can increase the $\mathrm{Hg}^{2+}$ proportion in flue gas before WFGD, which will enhance the overall mercury capture efficiency of WFGD. Therefore, the optimized strategy for WFGD is to stabilize the $\mathrm{Hg}^{2+}$ in the WFGD slurry to pre- vent mercury re-volatilization. The overall mercury removal efficiency of WFGD is on average $45 \%$ with a range of 10$85 \%$ (Yokoyama et al., 2000; Kilgroe et al., 2002; Ito et al., 2006; Lee et al., 2006; Meij and Winkel, 2006; Chen et al., 2007; Kim et al., 2010b; Wang et al., 2010a).

\subsubsection{Mercury transformation in wet scrubber (WS)}

Coal-fired industrial boilers are usually in a smaller scale compared with the utility boilers. The PM control for industrial boilers is not as advanced as those for power plants in developing countries. For example, WS is most widely adopted in China's industrial boilers. The proportion of $\mathrm{Hg}_{\mathrm{p}}$ in flue gas of industrial boilers (1-3\%) is not as high as that of power plants because of the shorter formation times of $\mathrm{Hg}_{\mathrm{p}}$ in industrial boilers, especially in small-scale ones. Consequently, the $\mathrm{Hg}_{\mathrm{p}}$ removal rate of WS is only about $50 \%$ (Zhang, 2012). $\mathrm{SO}_{2}$ in flue gas can dissolve in water and form $\mathrm{SO}_{3}^{2-}$, which could be a reducing agent for $\mathrm{Hg}^{2+}$, leading to low $\mathrm{Hg}^{2+}$ capture rates in WS (Chang and Ghorishi, 2003; Omine et al., 2012). The overall mercury removal rate of WS is $23 \%$ on average with a range of $7-59 \%$ (Zhang, 2012).

\subsection{Mercury speciation profile for coal-fired boilers}

Mercury speciation profiles in the flue gas from coal combustion are summarized in Table 1, which considers the transformation of mercury species across different types of APCDs (Goodarzi, 2004; Guo et al., 2004; Kellie et al., 2004; Tang, 2004; Duan et al., 2005; Lee et al., 2006; Zhou et al., 2006; Chen et al., 2007; Yang et al., 2007; Chen et al., 2008; Shah et al., 2008, 2010; Wang et al., 2008; Zhou et al., 2008; Kim et al., 2010b; Wang et al., 2010a; Zhang, 2012; Zhang et al., 2012a; L. Zhang et al., 2013b). When no APCD is applied, 
Table 1. Average speciation profiles (ranges) of mercury emissions from coal combustion by boiler type and control technology (\%).

\begin{tabular}{rllrrrr}
\hline No. & Boiler type & APCD combination & $\mathrm{Hg}^{0}$ & $\mathrm{Hg}^{2+}$ & $\mathrm{Hg}$ No. of tests \\
\hline 1 & PC/SF & None & $56(8-94)$ & $34(5-82)$ & $10(1-28)$ & 13 \\
2 & SF & WS & $65(39-87)$ & $33(10-60)$ & $2.0(0.2-4.5)$ & 6 \\
3 & PC & ESP & $58(16-95)$ & $41(5-84)$ & $1.3(0.1-10)$ & 31 \\
4 & PC & ESP+WFGD & $84(74-96)$ & $16(4-25)$ & $0.6(0.1-1.9)$ & 7 \\
5 & PC & SCR+ESP+WFGD & $74(16-96)$ & $26(4-84)$ & $0.2(0.1-0.4)$ & 6 \\
6 & PC & FF & $50(25-63)$ & $49(36-75)$ & $0.5(0.1-1.0)$ & 3 \\
7 & PC & FF+WFGD & 78 & 21 & 0.9 & 1 \\
8 & CFB & ESP & 72 & 27 & 0.6 & 1 \\
\hline
\end{tabular}

Notes: PC boiler - pulverized-coal boiler; SF boiler - stoker-fired boiler; CFB boiler - circulating fluidized bed boiler; WS - wet scrubber; ESP - electrostatic precipitator; FF - fabric filter; WFGD - wet flue gas desulfurization; SCR - selective catalytic reduction. References to Table 1 are listed in Sect. 2.3.

mercury speciation profile has the largest variability due to the different properties of coal burned. The average proportions of $\mathrm{Hg}_{\mathrm{p}}$ are all below $2 \%$ when PM control devices are installed. As commonly used for stoker-fired (SF) industrial boilers, WS removes a large proportion of $\mathrm{Hg}_{p}$ and a small proportion of $\mathrm{Hg}^{2+}$, resulting in a decrease of $\mathrm{Hg}_{\mathrm{p}}$ percentage and a slight increase of $\mathrm{Hg}^{0}$ percentage compared with the case of non-control. The average percentages of $\mathrm{Hg}^{0}$ and $\mathrm{Hg}^{2+}$ in the flue gas exhausted from ESP are 58 and $41 \%$, respectively. The presence of CFB boiler can increase the proportion of $\mathrm{Hg}^{0}$. The proportions of $\mathrm{Hg}^{0}$ and $\mathrm{Hg}^{2+}$ are similar in the flue gas after FF, although with large variability. For the combination of ESP+WFGD, the proportion of $\mathrm{Hg}^{0}$ reaches as high as $84 \%$. With the existence of SCR, the average proportion of $\mathrm{Hg}^{0}$ is not as high as that for the combination of ESP+WFGD because of the high oxidation rate of $\mathrm{Hg}^{0}$ inside SCR. Large uncertainties still exist in flue gas from the combinations of $\mathrm{PC}+\mathrm{FF}, \mathrm{PC}+\mathrm{FF}+\mathrm{WFGD}$ and $\mathrm{CFB}+\mathrm{ESP}$, since scarce speciation data are available.

\section{Mercury speciation and transformation in flue gases from non-ferrous metal smelters}

\subsection{Mercury speciation in the roasting and/or smelting furnaces}

Non-ferrous metals (zinc, lead, copper and industrial gold) are mainly produced from sulfide ores. Usually, mercury is released from concentrates to flue gases during the pyrometallurgical processes of non-ferrous metals. A typical pyrometallurgical process requires four stages, including dehydration, smelting and/or roasting, extraction, and refining (Wang et al., 2010b; Zhang et al., 2012b; Wu et al., 2015). Approximately $1 \%$ of mercury in concentrates is released to flue gas in the dehydration kiln, where the temperature varies from 150 to $700^{\circ} \mathrm{C}$ (Song, 2010). Mercury in concentrates is mainly released during smelting and/or roasting stage. The temperatures in the smelting/roasting, thermal extraction and thermal refining stages are all higher than $800^{\circ} \mathrm{C}$ ( $\mathrm{Li}$ et al.,
2010; Wang et al., 2010b). The Hg-S and $\mathrm{Hg}-\mathrm{O}$ bonds are broken under such high temperatures (Hylander and Herbert, 2008). Almost all mercury compounds are thermally dissociated into $\mathrm{Hg}^{0}$ considering the thermodynamic stability of $\mathrm{Hg}^{0}$ at this temperature (Wang, 2011). Mercury release rates during these stages are generally over $98 \%$ (Song, 2010; Li et al., 2010; Wu et al., 2015). The case in the industrial gold smelting process is an exception. Based on our on-site measurements, only $85 \%$ of the mercury in gold concentrate evaporates into the flue gas with the roasting temperature at $600^{\circ} \mathrm{C}$ (Yang, 2015). The low mercury release rate in the tested gold smelter may be related to chemical properties of mercury and gold. According to a previous study (Li, 1990), mercury at certain chemical speciation in gold ores only releases when the temperature exceeds $780^{\circ} \mathrm{C}$. The released $\mathrm{Hg}^{0}$ would be transformed to $\mathrm{Hg}^{2+}$ or $\mathrm{Hg}_{\mathrm{p}}$ by catalytic oxidation in the flue gas with the existence of gas phase oxidants such as atomic $\mathrm{Cl}$ (Galbreath and Zygarlicke, 2000; L. Zhang et al., 2013a).

\subsection{Mercury transformation across APCDs for the roasting and/or smelting flue gas}

Flue gases from the four stages typically go through dust collectors to remove particles. FF or ESP is generally adopted for flue gases from the dehydration, extraction, and refining stages, whereas a combination of waste heat boiler, cyclone and ESP is used for the roasting and/or smelting flue gas (Wu et al., 2012; UNECE, 2013). The flue gas is then cleaned in a purification system including flue gas scrubber (FGS) and electrostatic demister (ESD) before entering the acid plant for $\mathrm{SO}_{2}$ recovery (see Fig. 2). To minimize heavy metal emissions, the roasting and/or smelting flue gas could also require additional mercury removal after the purification system (UNECE, 2013). Since the roasting and/or smelting stage releases the most mercury, previous studies focus on mercury transformation and removal inside APCDs for the roasting/smelting flue gas (Zhang et al., 2012b; Wu et al., 2015). Figure 3 shows the mercury speciation after APCDs for non-ferrous metal smelters. Overall, the $\mathrm{Hg}_{\mathrm{p}}$ proportion 
is less than $5 \%$ for all non-ferrous metal smelters. $\mathrm{Hg}^{0}$ is the dominant species in the flue gas after the purification devices in most situations since most $\mathrm{Hg}^{2+}$ has been removed. However, when the flue gas goes through the acid plant, the share of $\mathrm{Hg}^{2+}$ increases to $80-98 \%$.

\subsubsection{Mercury transformation in the dust collectors}

Dust collectors can remove $>99 \%$ of particles and therefore $\mathrm{Hg}_{\mathrm{p}}$ is mostly removed simultaneously. $\mathrm{Hg}_{\mathrm{p}}$ proportion after dust collectors is less than 5\% (Zhang et al., 2012b; Wu et al., 2015). $\mathrm{Hg}^{0}$ can be homogeneously or heterogeneously oxidized in the flue gas, while the charging anode in the ESP can reduce $\mathrm{Hg}^{2+}$ to $\mathrm{Hg}^{0}$. Therefore, the resulting mercury speciation profile after the dust collectors depends on the competition between $\mathrm{Hg}^{2+}$ reduction and $\mathrm{Hg}^{0}$ oxidation. The proportion of $\mathrm{Hg}^{2+}$ after dust collectors varies a lot (4-85\%) among different tested smelters (Zhang et al., 2012b; Wu et al., 2015). The total mercury removal efficiency of dust collectors is usually less than $20 \%$. Test results of three zinc smelters showed mercury removal efficiencies of $9-12 \%$ (Wu et al., 2015). The study of $\mathrm{Li}$ et al. (2010) shows lower mercury removal efficiencies of dust collectors (1-5\%). ESP plays the most important role in mercury removal for roasting and/or smelting flue gas. Zhang et al. (2012b) found an average mercury removal rate of $12 \%$, which is much lower than the efficiency of ESPs in coal-fired power plants, because of two reasons. Firstly, higher temperature of ESPs in smelters $\left(300-350^{\circ} \mathrm{C}\right.$ compared to more or less $150^{\circ} \mathrm{C}$ in coal-fired power plants) would restrain the $\mathrm{Hg}^{0}$ condensation and $\mathrm{Hg}^{2+}$ absorption processes (Meij and Winkel, 2006). Secondly, although the dust concentrations in the flue gases of the coal-fired power plants and the nonferrous metal smelters are at the same level, mercury concentration in flue gas of non-ferrous metal smelters is two to three orders higher than that in the flue gas of coal-fired power plants (Tang et al., 2007; Wang et al., 2010a, b; Zhang, 2012; Zhang et al., 2012a, b; Wu et al., 2015). Under such conditions, there might not be sufficient active sites on the particles for mercury adsorption in the flue gas of non-ferrous metal smelters.

\subsubsection{Mercury transformation in purification systems}

The purification system generally includes FGS and ESD. Unlike WS or WFGD for $\mathrm{SO}_{2}$ control in coal combustion, FGS in non-ferrous metal smelters uses diluted sulfuric acid to capture $\mathrm{SO}_{2}$ and $\mathrm{SO}_{3}$. The yield from FGS is waste acid, which will be treated to acid sludge. ESD is employed to remove water vapor from flue gas. Li et al. (2010) and Wang et al. (2010b) found that mercury removal efficiency in FGS was $11-22 \%$, whereas ESD removed $10-42 \%$ of total mercury in the flue gas. The overall mercury removal efficiency of the purification systems in six tested plants by Zhang et al. (2012b) varies in the range of 72-99\%. Studies of Zhang et al. (2012b) and Kim et al. (2011) show that higher $\mathrm{Hg}^{2+}$ in the flue gas entering the purification system leads to higher mercury removal efficiency considering the high solubility of $\mathrm{Hg}^{2+}$ in water and sulfuric acid. In addition, $\mathrm{Hg}^{0}$ would condense to liquid metallic mercury when the temperature of flue gas decreases from $300^{\circ} \mathrm{C}$ to approximately $25^{\circ} \mathrm{C}$ at the outlet of the purification system (Song, 2010). Previous studies have observed liquid $\mathrm{Hg}^{0}$ in the removed waste acid (Wang, 2011). The dominant mercury species after the purification system is generally $\mathrm{Hg}^{0}$, with a proportion $43-96 \%$ (Wang et al., 2010b; Zhang et al., 2012b; Wu et al., 2015).

\subsubsection{Mercury transformation in dedicated mercury removal systems}

Mercury in the flue gas can be removed by dedicated techniques including Boliden-Norzink process, Bolchem process, Outokumpu process, sodium thiocyanate process, selenium scrubber, activated carbon filters, and selenium filter (UNECE, 2013). The removal mechanisms in these processes are either to oxidize $\mathrm{Hg}^{0}$ into $\mathrm{Hg}^{2+}$ or $\mathrm{Hg}^{+}$with strong oxidants and then remove oxidized mercury, or to capture $\mathrm{Hg}^{0}$ with specific adsorbents. The Boliden-Norzink process, the most widely used process in non-ferrous metal smelters, has been installed in more than 40 smelters globally. On-site measurements indicated that its mercury removal efficiency is $83-92 \%$ (Wang et al., 2010b; Li et al., 2010; $\mathrm{Wu}$ et al., 2015). In the Boliden-Norzink process, $\mathrm{Hg}^{0}$ in the flue gas is oxidized to $\mathrm{Hg}_{2} \mathrm{Cl}_{2}$ by solution containing $\mathrm{HgCl}_{2}$. The yield $\mathrm{Hg}_{2} \mathrm{Cl}_{2}$ is removed from the circulating solution and then either used for mercury production or stored, whereas the solution is reused after regeneration. Other processes are not as commercialized as the BolidenNorzink process.

\subsubsection{Mercury transformation in the acid plants}

An acid plant generally includes a dehydration tower, a conversion tower, and an absorption tower. A dehydration tower uses $93-95 \%$ sulfuric acid to remove the water vapor. A conversion tower converts $\mathrm{SO}_{2}$ into $\mathrm{SO}_{3}$ with vanadium catalysts. An absorption tower absorbs $\mathrm{SO}_{2}$ with $98 \%$ sulfuric acid. Tests in one zinc smelter with a mercury reclaiming tower indicates that mercury speciation profile $\left(\mathrm{Hg}^{0}: \mathrm{Hg}^{2+}: \mathrm{Hg}_{\mathrm{p}}\right)$ after the acid plant is $6: 90: 4$ (Wang et al., 2010b). Wu et al. (2015) found that the proportion of $\mathrm{Hg}^{2+}$ increased from 4 to $98 \%$ when passing the acid plant. The total mercury removal efficiency in the acid plant can reach $83 \%$. On-site measurements in six smelters by Zhang et al. (2012b) showed that the dominant species was $\mathrm{Hg}^{2+}$ after the acid plant with the double-conversion-doubleabsorption process, while $\mathrm{Hg}^{0}$ became the dominant species after the single-conversion-single-absorption process. The net reaction of mercury in the acid plant is the oxidation of $\mathrm{Hg}^{0}$, either by the oxidants in flue gas under the vanadium 


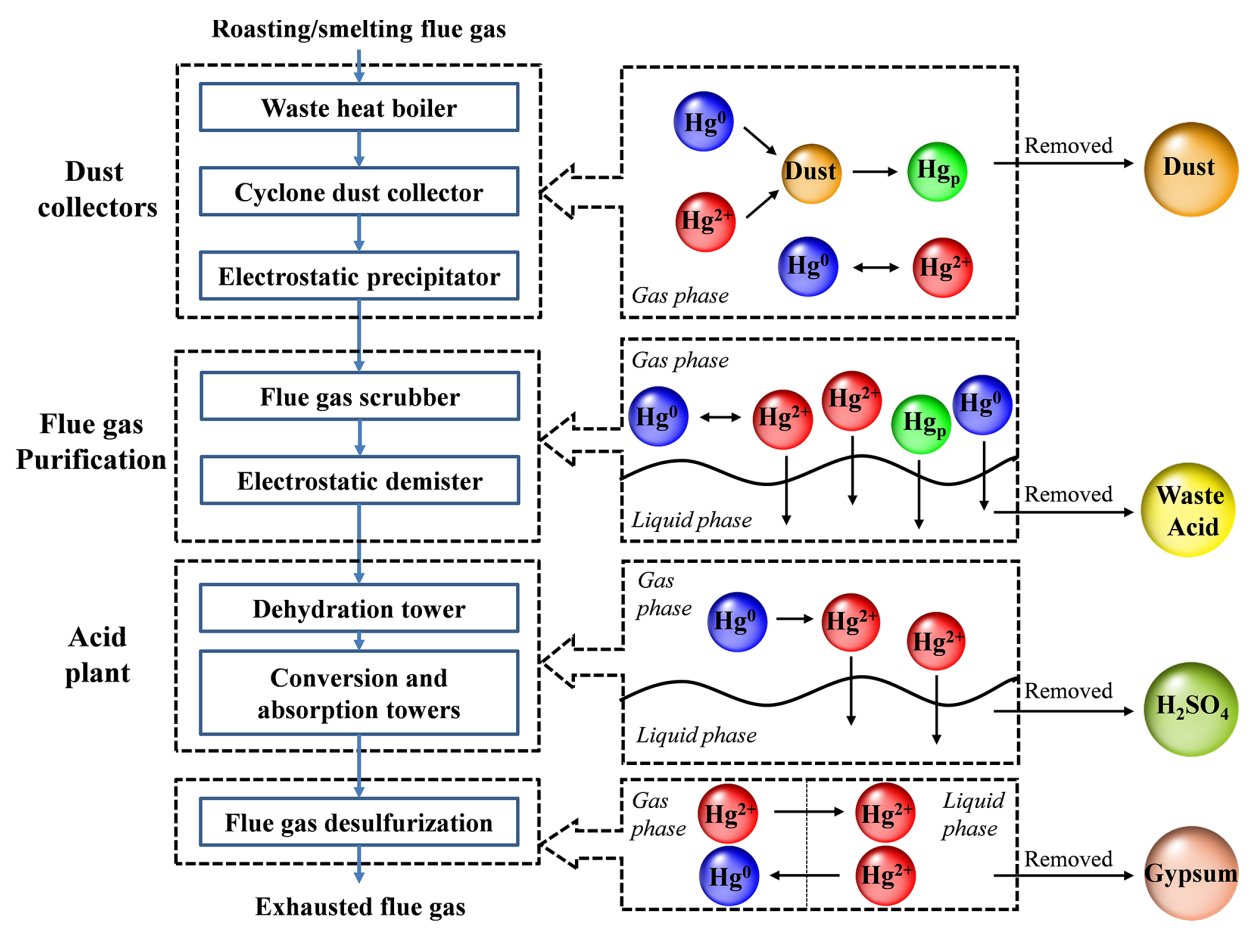

Figure 2. Mercury transformation and removal in roasting and/or smelting flue gas.

catalysts in the conversion tower or by the concentrated sulfuric acid. However, further studies are required to understand the oxidation mechanisms.

\subsection{Mercury speciation profile for non-ferrous metal smelters}

Mercury speciation profiles in the flue gases from nonferrous metal smelters are summarized in Table 2 . In early mercury emission inventories, the relative emission proportions (REPs) among $\mathrm{Hg}^{0}: \mathrm{Hg}^{2+}: \mathrm{Hg}_{\mathrm{p}}$ species for nonferrous metal smelters were estimated to be $80: 15: 5$ (Pacyna and Pacyna, 2002; Streets et al., 2005; Pacyna et al., 2006; Wu et al., 2006). However, recent field tests found that the proportion of $\mathrm{Hg}^{2+}$ could reach $>90 \%$ for the smelting and/or roasting stage with acid plants (Wang et al., 2010b; Zhang et al., 2012b). Besides the smelting and/or roasting stage, mercury emissions from the slag dehydration and volatilization stages are also significant. According to field experiments in a zinc smelter (Wang et al., 2010b), the mercury emissions from these two stages were 95 and $50 \mathrm{~g} \mathrm{~d}^{-1}$, respectively, even higher than that from the roasting process $\left(22 \mathrm{~g} \mathrm{~d}^{-1}\right)$. Therefore, the overall mercury speciation profile for non-ferrous metal smelters is not only affected by the roasting and/or smelting flue gases but also by the dehydration flue gas and the volatilization flue gas. Mass flow analysis in three zinc smelters indicates that mercury emissions from the slag dehydration stage, the slag smelting stage and the volatilization stage accounted for $54-98 \%$ of total emissions, with $\mathrm{Hg}^{0}$ as the dominant form (Wu et al., 2015). When considering atmospheric mercury emissions from all thermal processes in addition to the roasting process, the emission proportion of $\mathrm{Hg}^{2+}$ is reduced to 29-51\% (Wu et al., 2015). In lead smelters, the proportion of $\mathrm{Hg}^{2+}$ is about $40 \%$ when considering atmospheric mercury emissions from the extracting and reclaiming processes (Zhang et al., 2012b). The proportion of $\mathrm{Hg}^{2+}$ in all exhausted gases is $32-68 \%$ in copper smelters with the doubleconversion-double-absorption process installed for the roasting flue gas (Zhang et al., 2012b). The mercury speciation profile $\left(\mathrm{Hg}^{0}: \mathrm{Hg}^{2+}: \mathrm{Hg}_{\mathrm{p}}\right)$ in the exhausted flue gases in gold smelters with the double-conversion-double-absorption process is estimated to be $32: 57: 11$ (Yang, 2015).

\section{Mercury speciation and transformation in flue gas from cement clinker production}

\subsection{Cement clinker production processes}

A mix of raw materials, mainly limestone, are heated up to over $1400^{\circ} \mathrm{C}$ and different compositions react to produce clinker. Additives, usually gypsum, are then mixed with clinker and milled to produce cement. The temperature of the final cement production is usually under $100^{\circ} \mathrm{C}$. Results from temperature programmed decomposition (TPD) experiments indicate that mercury is not released from gypsum at such temperatures (Rallo et al., 2010; López-Antón et al., 2011; Liu et al., 2013). Therefore, we only consider the 
Table 2. Average speciation profiles of mercury emissions from non-ferrous metal smelters by control technology $(\%)$.

\begin{tabular}{llcrrl}
\hline Metal type & APCD combinations & $\mathrm{Hg}^{0}$ & $\mathrm{Hg}^{2+}$ & $\mathrm{Hg}_{\mathrm{p}}$ & Reference \\
\hline Non-ferrous metal & N.S. & 80 & 15 & 5 & $\begin{array}{l}\text { Streets et al. (2005) } \\
\text { Pacyna et al. (2006) } \\
\text { Wu et al. (2006) }\end{array}$ \\
& & & & & \\
\hline Zinc & $\mathrm{DC}+\mathrm{PS}+\mathrm{MRT}+\mathrm{AP}_{\mathrm{d}}$ & 71 & 28 & 1 & Wu et al. (2015) \\
\hline Zinc & $\mathrm{DC}+\mathrm{PS}+\mathrm{AP}_{\mathrm{d}}$ & 55 & 44 & 1 & $\begin{array}{l}\text { Zhang et al. (2012b) } \\
\text { Wu et al. (2015) }\end{array}$ \\
\hline Lead & $\mathrm{DC}+\mathrm{PS}+\mathrm{AP}_{\mathrm{s}}$ & 40 & 60 & 0 & $\begin{array}{l}\text { Zhang et al. (2012b) } \\
\text { Copper }\end{array}$ \\
\hline DC $+\mathrm{PS}+\mathrm{AP}_{\mathrm{d}}$ & 39 & 61 & 0 & Zhang et al. (2012b) \\
\hline Gold & $\mathrm{DC}+\mathrm{PS}+\mathrm{AP}_{\mathrm{d}}$ & 50 & 50 & 0 & Zhang et al. (2012b) \\
\hline
\end{tabular}

Notes: N.S. - not specific; DC - dust collector; PS - purification system; MRT - mercury reclaiming tower; $\mathrm{AP}_{\mathrm{d}}-$ acid plant with double-conversion-double-absorption processes; $\mathrm{AP}_{\mathrm{S}}$ - acid plant with single-conversion-single-absorption processes.

clinker production process that includes shaft kilns, wet rotary kilns, dry rotary kilns, and precalciner processes.

Precalciner process is usually composed of the raw mill system, the coal mill system, the kiln system and the kiln head system. Raw materials are ground and homogenized in the raw mill system. The fuel, usually coal, is prepared in the coal mill system including coal mill and FF. The kiln system for the production of cement clinker includes the preheater, the precalciner, and the rotary kiln. The prepared raw materials, namely raw meal, enter the kiln system from one end of rotary kiln (kiln tail), and the coal powder is brought into the kiln system by air from the other kiln end (kiln head). The solid materials flow in opposite direction with the flue gas. The flue gas from kiln tail is used to preheat raw materials in raw mill and coal in coal mill. The flue gas from kiln head is de-dusted and then emitted into the atmosphere. All the dust collected by dust collector is recycled to kiln system.

\subsection{Mercury behavior in cement clinker production process}

The mercury behavior in cement production process is summarized as three stages: vaporization, adsorption, and recycling (Sikkema et al., 2011) (see Fig. 4). At the vaporization stage, mercury in raw materials and fuel is vaporized into flue gas in the kiln system. Then part of the mercury in flue gas is captured by raw materials in the raw mill and coal in the coal mill when the flue gas is used to preheat solid materials, and part of the mercury in flue gas is also collected in the dust collector with dust. This process is called the adsorption stage. Finally, the mercury is cycled back into the kiln system with raw materials, coal and collected dust, which is the recycling stage. Therefore, there are three mercury cycles in the precalciner clinker production process. Mercury cycling in cement plants has been confirmed in field tests (Mlakar et al., 2010; Paone, 2010; Sikkema et al., 2011; Zheng et al.,

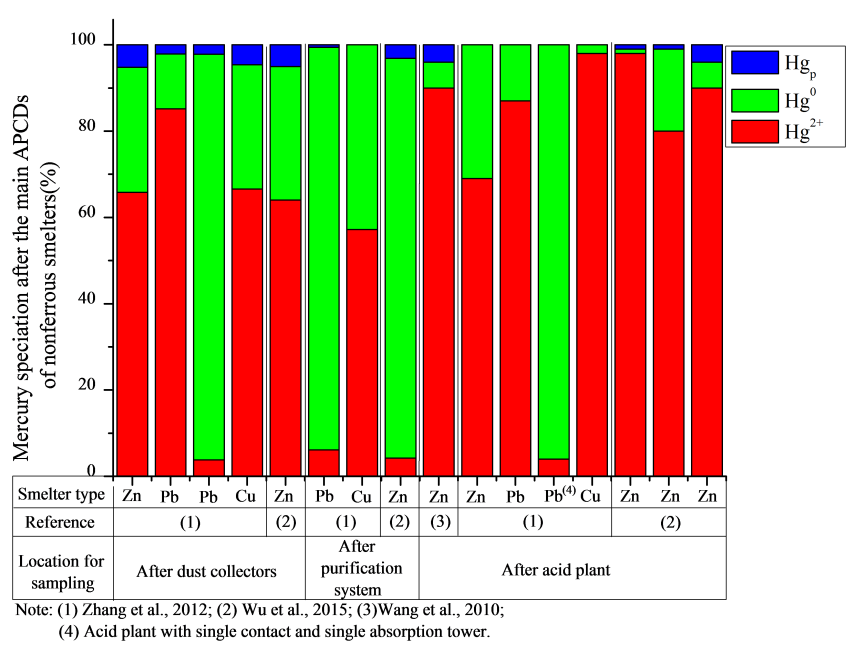

Figure 3. Mercury speciation after APCDs for non-ferrous metal smelters.

2012). A transient model was developed to simulate mercury concentration in flue gas from kiln tail (Senior et al., 2010). This model was based on a series of mass balances from preheater to the whole process.

The three mercury cycles cause mercury enrichment in the clinker production process. F. Y. Wang et al. (2014) assessed mercury enrichment process using the ratio of mercury concentration in the exhausted flue gas to the equivalent mercury concentration. The equivalent mercury concentration was defined by dividing the total mercury input from raw materials and coal with the total amount of flue gas emerged in the kiln system. It was found that the mercury concentration was enriched by as high as 4-15 times in two Chinese cement plants. Another study also confirmed this point, with the mercury concentration enriched by over 10 times (Mlakar et al., 2010). 


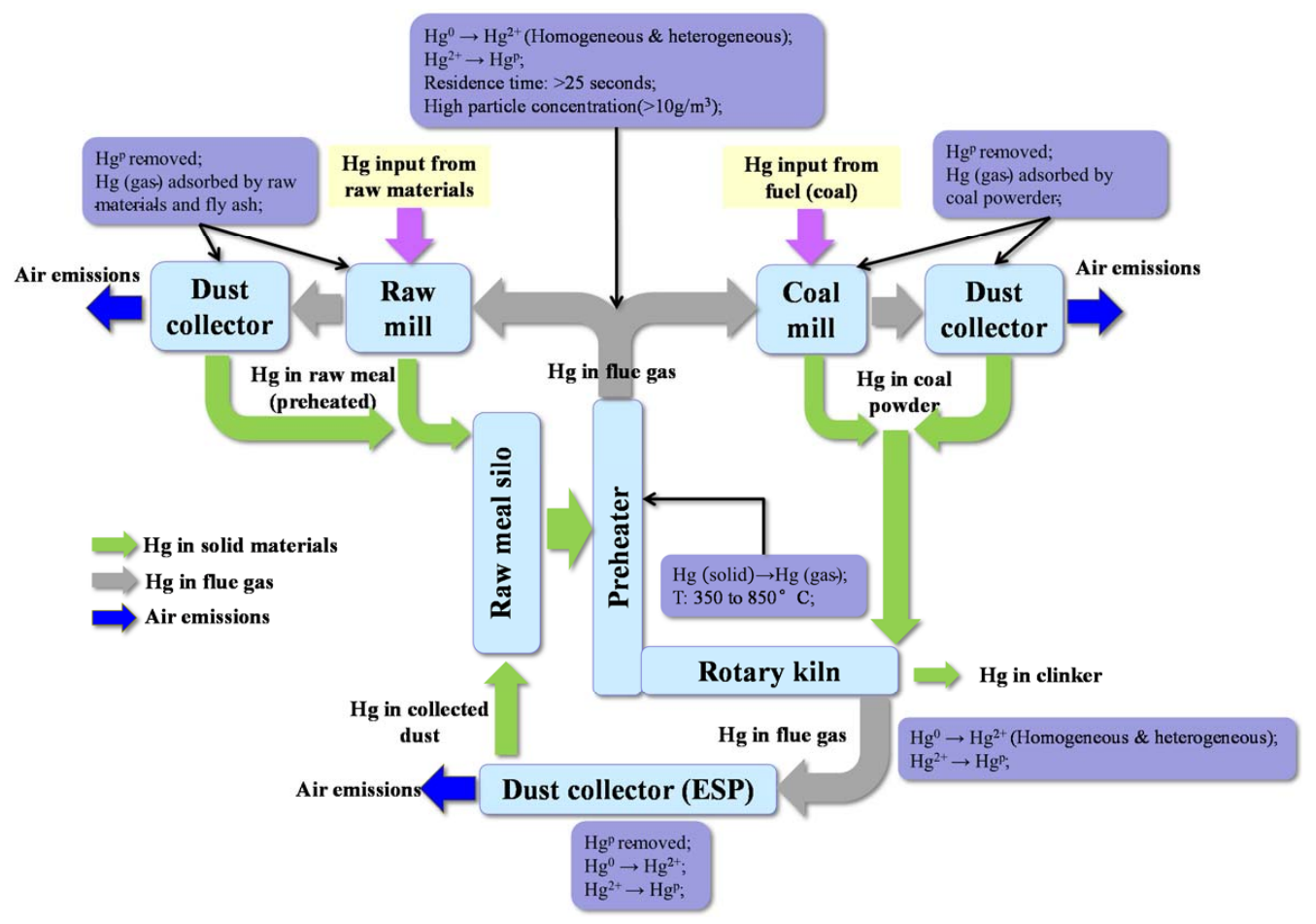

Figure 4. Mercury transformation in the precalciner cement production process.

Mercury enrichment can affect its emission from cement plants. The cement clinker production process has two modes depending on the operation of raw mill. When the raw mill is on (operation mode), the flue gas flows through raw mill first and then emitted into the atmosphere after dust removal. When the raw mill is off (direct mode), the flue gas directly flows through the FF after the raw mill and emits into the atmosphere. In operation mode, a larger proportion of mercury in flue gas is recirculated and enriched in the system because the combination of raw mill and FF has a higher mercury removal efficiency than FF alone. Therefore, switching between the two modes significantly changes mercury enrichment and concentration in flue gas. It should be noted that mercury concentration in the clinker is low. If no filtered dust is discarded, over $90 \%$ of mercury input from raw materials and coal is eventually emitted into the atmosphere (Paone, 2008; Linero, 2011; Hoenig and Zunzer, 2013).

\subsection{Mercury transformation during cement clinker production process}

In mercury vaporization stage, mercury in raw materials and coal is released into the flue gas. Field tests in power plants of previous studies indicated that almost all of the mercury in coal (>99\%) was vaporized into the flue gas as the elementary form because of the high temperature in coal-fired boilers, which is usually higher than $1000^{\circ} \mathrm{C}$ (Tang et al., 2007; Wang et al., 2010a; Zhang et al., 2012a). For the cement clinker production process, mercury in raw materials and coal is mostly released to the flue gas. Mercury concentration in clinker was less than $5 \mathrm{ng} \mathrm{g}^{-1}$, accounting for only $1.9-6.1 \%$ of the total mercury (F. Y. Wang et al., 2014). The compounds of mercury silicates might be the main chemical forms of mercury in clinker (Schreiber et al., 2005). Temperature of raw materials increases continuously from $400^{\circ} \mathrm{C}$ at the inlet of the preheater to over $1400^{\circ} \mathrm{C}$ in the rotary kiln. Different mercury species have different decomposition and boiling temperatures, as summarized in one previous study (Zheng et al., 2012). Further studies on identification of mercury species in raw meals are needed to understand the mechanism of mercury vaporization in kiln system.

Mercury is oxidized homogeneously and heterogeneously in flue gas. As analyzed by F. Y. Wang et al. (2014), a series of operational conditions in the cement clinker production process can promote mercury oxidation. The oxidation of mercury is usually kinetically limited (Senior et al., 2000; Niksa et al., 2001; Wilcox et al., 2003; Krishnakumar and Helble, 2007; Liu et al., 2010). Residence time over 20 s provides enough reaction time for mercury oxidation. The high concentration of PM in flue gas, usually over $10 \mathrm{~g} \mathrm{~m}^{-3}$, can catalyze the oxidation; and the addition of Fe-containing material in raw materials can provide more active sites for heterogeneous mercury oxidation (Dunham et al., 2003; Galbreath et al., 2005; Bhardwaj et al., 2009). Vaporized $\mathrm{Hg}^{0}$ in the kiln system is oxidized during the cooling process of flue gas. Considering that $\mathrm{Hg}^{2+}$ can be easily adsorbed onto the surface of PM in flue gas and the PM concentration in flue 
gas is high, the proportion of $\mathrm{Hg}_{\mathrm{p}}$ is therefore high. Mercury speciation in the flue gas entering the raw mill system was measured in three cement plants (F. Y. Wang et al., 2014). The proportion of $\mathrm{Hg}^{2+}$ was in the range of $64-76 \%$, while the proportion of $\mathrm{Hg}_{\mathrm{p}}$ was $21-27 \%$. Mlakar et al. (2010) found that the proportion of $\mathrm{Hg}_{\mathrm{p}}$ in another plant was even higher, ranging from 15 to $77 \%$. The high proportion of $\mathrm{Hg}^{2+}$ and $\mathrm{Hg}_{\mathrm{p}}$ can cause a high mercury removal efficiency in APCDs and other facilities, including dust collectors, raw mill and coal mill. Mercury removal efficiencies of raw mill with FF and coal mill with FF could reach 86-89 and 94$95 \%$, respectively (F. Y. Wang et al., 2014). The mechanisms of mercury removal in raw mill and FF are different. The removal of $\mathrm{Hg}_{\mathrm{p}}$ in $\mathrm{FF}$ and adsorption of $\mathrm{Hg}^{2+}$ onto the filter cake are considered to be the predominant mechanism in FF (Chen et al., 2007; Wang et al., 2010a). At mercury recycling stage, the removed mercury in raw mill, coal mill and dust collectors is eventually cycled into kiln system with raw mill, coal powder and dust, respectively. Overall, because of the existing mercury cycling and a series of operational conditions promoting mercury oxidation, mercury speciation during clinker production is dominated by $\mathrm{Hg}^{2+}$ and $\mathrm{Hg}_{\mathrm{p}}$.

\subsection{Mercury speciation profile for cement plants}

The mercury emissions from the cement clinker production process were previously considered to be composed of $80 \%$ $\mathrm{Hg}^{0}, 15 \% \mathrm{Hg}^{2+}$, and $5 \% \mathrm{Hg}_{\mathrm{p}}$ (Streets et al., 2005). Recent field results (Mlakar et al., 2010; Won and Lee, 2012; F. Y. Wang et al., 2014) on mercury emission speciation of cement production are shown in Table 3. The proportions of different mercury species fluctuate at a wide range. Won and Lee (2012) found that $\mathrm{Hg}^{2+}$ only accounted for $15 \%$ of the total mercury emissions, while other studies (VDZ, 2002; Mlakar et al., 2010; Linero, 2011; F. Y. Wang et al., 2014) showed that $\mathrm{Hg}^{2+}$ was the dominant species accounting for 60 to $>90 \%$ of the total mercury. As discussed above, the mercury speciation and emission are largely variable because of the complicated mercury cycling and operational modes of the cement clinker production process. Previous estimates of mercury emission and speciation from cement clinker production have large uncertainties. More studies including field tests should be conducted to further understand the mechanism of mercury speciation and transformation in cement production.

\section{Mercury speciation and transformation in flue gases from other emission sources}

In this section, the behavior of mercury in flue gases from other emission sources, including iron and steel production, waste incineration, biomass burning, cremation, and PVC production, are introduced. Although there are still other mercury emission sources not discussed in this study, such as oil combustion, few field measurements are available for mercury speciation and transformation inside these sources.

\subsection{Mercury speciation and transformation in flue gas from iron and steel production}

Iron and steel production is composed of raw material preparation (rotary kilns for limestone and dolomite production and the coking process), sintering machine, blast furnace and convertor. In raw material preparation, limestone and dolomite are roasted in rotary kilns and coking coal is produced in a coke oven. Iron ores, coke, and limestone (dolomite) are then mixed and roasted in the sintering machine, namely the sintering process. Products of these two stages are fed to the blast furnace where sinter, coke, and limestone are smelted to produce iron, and then the iron is smelted in a convertor to produce steel. There is also another process using steel scrap to produce steel, called electric furnace. To increase the utilization efficiency of energy, coal gas emerged in the coke oven, blast furnace and convertor is collected and burned to generate electricity. The operational conditions in different stages are quite different. The mercury behavior in iron and steel plants is therefore quite complicated.

Mercury is vaporized in high-temperature facilities, including coke oven, sintering machine, blast furnace and convertor. Mercury in the flue gas is oxidized homogeneously and heterogeneously. Part of the mercury is removed in dust collectors and flue gas desulfurization devices, and the remaining mercury in flue gas is emitted into the atmosphere. Field tests indicated that the mercury release rates in coke oven and sintering machine were lower than that in coalfired boilers $(>99 \%)$ because of the lower temperature in these facilities (Wang et al., 2016b). Previous studies indicated that the mercury emissions from sintering machine accounted for about $90 \%$ of total emissions from iron and steel plants (Fukuda et al., 2011). A speciation profile of $80 \% \mathrm{Hg}^{0}, 15 \% \mathrm{Hg}^{2+}$ and $5 \% \mathrm{Hg}_{\mathrm{p}}$ was applied in Streets et al. (2005). However, oxidized mercury was found to be the predominant species in our recent study (Wang et al., 2016b). The proportion of $\mathrm{Hg}^{2+}$ in flue gas reached as high as 59$73 \%$ and the proportion of $\mathrm{Hg}_{\mathrm{p}}$ was under the detection limit because of the installation of ESPs for the examined iron and steel plants (Wang et al., 2016b). The high PM concentration in flue gas and Fe on PM could promote mercury oxidation in flue gas. More field tests need to be conducted on mercury speciation profile of this industry in the future.

\subsection{Mercury speciation and transformation in flue gas from waste incineration}

Waste incineration is a potential predominant source in the global mercury emission inventory. The major incineration types are municipal solid waste (MSW) incineration, medical waste incineration and industrial and/or hazardous waste 
Table 3. Average proportions of emitted mercury species from cement clinker production (\%).

\begin{tabular}{lrrrl}
\hline Production processes & $\mathrm{Hg}^{0}$ & $\mathrm{Hg}^{2+}$ & $\mathrm{Hg}_{\mathrm{p}}$ & References \\
\hline N.S. & 80 & 15 & 5 & Streets et al. (2005) \\
N.S. & 85 & 15 & 0 & Won and Lee (2012) \\
Precalciner process (raw mill off) & 16.0 & 75.7 & 8.3 & Mlakar et al. (2010) \\
Precalciner process (raw mill on) & 43.1 & 45.5 & 11.4 & Mlakar et al. (2010) \\
Precalciner process & 9.2 & 90.8 & 0.0 & F. Y. Wang et al. (2014) \\
Precalciner process & 38.7 & 61.3 & 0.0 & F. Y. Wang et al. (2014) \\
Precalciner process & 23.4 & 75.1 & 1.6 & F. Y. Wang et al. (2014) \\
\hline
\end{tabular}

Note: N.S. - not specific.

incineration. A significant proportion of mercury (80-96\%) in the MSW releases from the incinerator into the flue gas is in the form of $\mathrm{Hg}^{0}$ at $850-1000{ }^{\circ} \mathrm{C}$ (Park et al., 2008). Grate furnace combustor (GFC) and circulation fluidized bed combustor (CFBC) are the two most commonly used incinerators. The flue gas from CFBC has a larger proportion of $\mathrm{Hg}_{\mathrm{p}}$ than that from GFC. Typical APCDs for incinerators are combinations of semi-dry or dry flue gas deacidification (SD-FGD or D-FGD) for $\mathrm{SO}_{2}$ and $\mathrm{HCl}$ removal and dust controller (e.g., $\mathrm{WS}+\mathrm{ESP}, \mathrm{FF}, \mathrm{FF}+\mathrm{WS}$, etc.). SCR is sometimes used as well for $\mathrm{NO}_{x}$ control. Activated carbon injection (ACI) is used for the control of persistent organic pollutants (POPs), which is required for incinerators in China.

The overall mercury removal efficiency of the APCDs for MSW incineration ranges from $60 \%$ to over $99 \%$ (Zhang et al., 2008; Takahashi et al., 2012). Previous studies in Europe and the USA indicated that the $\mathrm{Hg}^{2+}$ proportion in the exhausted flue gas ranges from 75 to $85 \%$ (Pacyna and Münch, 1991; Carpi, 1997). A Korean study found the $\mathrm{Hg}^{2+}$ proportion in MSW incinerators to be in the range of 78-89\%, and that in industrial waste incinerators are even as high as 96.3-98.7\% (Park et al., 2008). Kim et al. (2010a) tested two medical waste incinerators with SD-FGD+FF+WS and got the $\mathrm{Hg}^{0}$ proportion to be 43.9 and $96.8 \%$ respectively. A Japanese study showed that an industrial waste incinerator with WS and wet ESP has the $\mathrm{Hg}^{0}$ proportion of 92.7\% (Takahashi et al., 2012). Based on field measurements in eight MSW incinerators in China, Chen et al. (2013) found that average $\mathrm{Hg}^{2+}$ proportion in flue gas from the outlet of GFC+SD-FGD+ACI+FF is $96 \%$, while that for $\mathrm{CFBC}+\mathrm{SD}-\mathrm{FGD}+\mathrm{ACI}+\mathrm{FF}$ is $64 \%$. High chlorine content in the waste results in high $\mathrm{Hg}^{2+}$ proportion in the flue gas. Limestone slurry or powder sprayed in SD-FGD or D-FGD absorbs a large amount of $\mathrm{Hg}^{2+}$ and activated carbon adsorbs a large amount of both $\mathrm{Hg}^{0}$ and $\mathrm{Hg}^{2+}$. Particles from SDFGD and ACI are captured by the downstream FF. $\mathrm{Hg}_{\mathrm{p}}$ is removed by all types of dust controllers. The high $\mathrm{Hg}^{2+}$ formation rate due to the oxidative condition in flue gas and the high $\mathrm{Hg}^{2+}$ removal rate by APCDs (especially SD-FGD, FF and $\mathrm{ACI}$ ) cause the significant variation in mercury speciation profiles for incinerators.

\subsection{Mercury speciation and transformation in flue gas from biomass burning}

Biomass burning mainly includes biomass fuel burning and open biomass burning. Biomass fuel can be divided into fuel woods, crop residues and biomass pellets. Usually, there is no APCD for biomass burning. Huang et al. (2011) tested four different types of wood fuels and found the $\mathrm{Hg}^{0}$ proportion to be $95-99 \%$ and the rest is basically $\mathrm{Hg}^{2+}$. Wei (2012) found that $\mathrm{Hg}^{0}$ in flue gas from biomass burning is $70-90 \%$ of total mercury while that of $\mathrm{Hg}^{2+}$ ranges from 5 to $9 \%$. $\mathrm{Hg}_{\mathrm{p}}$ proportion differs a lot between different biomass fuel types: 12 , 25 and $1 \%$ for fuel wood, crop residues and biomass pellets, respectively. Hu et al. (2012) differentiated the emission factors for biomass burning and cooking and/or space heating in rural areas to be 0.035 and $0.515 \mathrm{~g} \mathrm{Hg} \mathrm{t}^{-1}$ biomass burned, respectively. W. Zhang et al. (2013) tested 25 types of fuel wood, 8 types of crop residues and 2 types of biomass pellets, and found that the mercury emission rate during biomass burning is 78-99\% while the remainder stays in the residue. The mercury speciation profile (ratio of $\mathrm{Hg}^{0}, \mathrm{Hg}^{2+}$ and $\mathrm{Hg}_{\mathrm{p}}$ to total $\mathrm{Hg}$ ) for fuel wood was 76,6 , and $18 \%$, and that for crop residue was similar $(73,4$, and $23 \%)$. However, the speciation profile for biomass pellets is quite different. Due to the more complete combustion, $\mathrm{Hg}^{0}$ accounts for as high as $97 \%$ in the flue gas from biomass pellets combustion. W. Zhang et al. (2013) calculated mercury emission from biomass burning in China and gave the shares of $\mathrm{Hg}^{0}$, $\mathrm{Hg}^{2+}$ and $\mathrm{Hg}_{\mathrm{p}}$ at 74,5 , and $21 \%$, respectively. Open biomass burning generally involves forest wildfires, grassland and/or savanna wildfires, and agriculture residue burning. Friedli et al. (2003) investigated the mercury speciation from burning of temperate North American forests through both laboratory and airborne measurements. Their research showed that the dominant species is $\mathrm{Hg}^{0}$, accounting for $87-99 \%$ of the total mercury, and the rest is mainly $\mathrm{Hg}_{\mathrm{p}}$. 


\subsection{Mercury speciation and transformation in flue gas from cremation}

Researches on mercury speciation and transformation in flue gas from cremation are very limited. Takaoka et al. (2010) conducted field measurements in seven crematories in Japan, two of them without any APCDs, one with ESP and four with FF for particle control. Advanced APCDs such as catalytic reactor and activated carbon filter are installed in three of the tested crematories. In the exhausted flue gases, $\mathrm{Hg}^{0}$ is on average the dominant mercury species but with significant variation (25-99\%). Extremely large uncertainties exist in this sector due to the large diversity of mercury content in human body and whether the dental amalgam is applied.

\subsection{Mercury speciation and transformation in flue gas from PVC production}

Aside from combustion and some high-temperature industrial processes, there are some other processes with intentional mercury use that also have mercury emissions. The production of polyvinyl chloride (PVC) with the calcium carbide process utilizes a catalyst containing large amounts of mercury. Ren et al. (2014) conducted on-site measurements in a PVC production line and found that $71.5 \%$ of the total mercury was lost from the catalyst, most of which was recovered by the mercury remover, accounting for $46 \%$ of the total mercury. The total mercury emitted to the atmosphere only accounted for less than $1 \%$ of the total mercury in the catalyst. The speciation tests indicated that most of the mercury escaped from the catalyst was $\mathrm{Hg}^{0}$, as no $\mathrm{Hg}^{2+}$ was detected virtually.

\section{Comparison of mercury speciation profiles in different countries and regions}

Table 4 summarizes the sectoral mercury speciation profiles in different countries and regions (Pacyna et al., 2006; AMAP/UNEP, 2008; Chrystall and Rumsby, 2009; Kim et al., 2010a; Lin et al., 2012; Nelson et al., 2012; Zhang et al., 2015). China and South Korea have compiled extensive speciation profiles based on observational data collected at anthropogenic mercury emission sources. The inventories for Europe and New Zealand used the same speciation data as the global inventory for coal combustion, which is close to the results of South Korea. China has different speciation data for coal combustion, where the proportion of $\mathrm{Hg}^{0}$ is higher than that reported in other countries. This is probably because the high WFGD installation rate in China results in higher $\mathrm{Hg}^{2+}$ removal efficiency. Mercury speciation for coal-fired power plants, industrial and residential coal combustion are also different. Residential coal combustion has the lowest $\mathrm{Hg}^{2+}$ proportion while industrial coal combustion has the highest. This is mainly influenced by the boiler type and the APCDs applied. Residential stove has

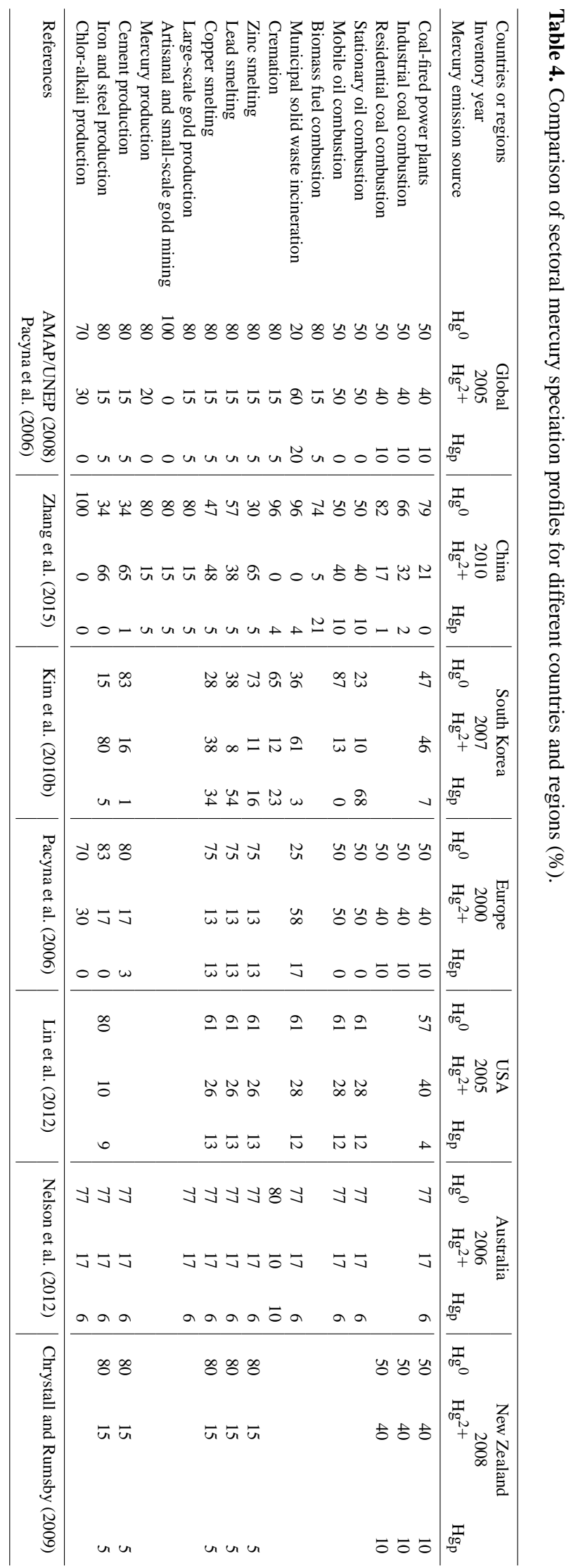


a short temperature-decrease time, which reduces formation of $\mathrm{Hg}^{2+}$. The APCDs applied for industrial coal combustion have a lower $\mathrm{Hg}^{2+}$ removal efficiency than those applied for coal-fired power plants.

Global inventory applied similar speciation profiles for most other industrial sectors, i.e., $80 \% \mathrm{Hg}^{0}, 15 \% \mathrm{Hg}^{2+}$ and $5 \% \mathrm{Hg}_{\mathrm{p}}$. The inventories estimated in China and South Korea provide speciation profiles for different sectors. The sectors of non-ferrous metal smelting (including zinc, lead, and copper), cement production and iron and steel production in China have higher $\mathrm{Hg}^{2+}$ proportions than most of the other countries, which is caused by catalytic mercury oxidation in acid plants in non-ferrous metal smelters and the intensive heterogeneous mercury oxidation in cement plants and steel plants. The higher $\mathrm{Hg}^{2+}$ proportions imply that mercury emission from East Asia could have more local environmental impacts than previously expected. Our recent study (L. Wang et al., 2014) indicated that anthropogenic sources in China contribute $35-50 \%$ of the total mercury concentration and $50-70 \%$ of the total deposition in polluted regions in China.

\section{Conclusions}

The initial speciation of mercury after the boiler, smelter or kiln varies significantly because of the diverse qualities of coals or raw materials. Nearly all mercury in coal is released into the flue gas in the form of $\mathrm{Hg}^{0}$ during combustion. $\mathrm{Hg}^{0}$ is the predominant mercury species in exiting flue gases from coal-fired power plants mainly due to the high $\mathrm{Hg}_{\mathrm{p}}$ removal efficiency of ESP or FF and the high $\mathrm{Hg}^{2+}$ removal efficiency of WS or WFGD. The enhancement of $\mathrm{Hg}^{0}$ oxidation in SCR and by halogen injection is effective for mercury emission control in coal-fired power plants. On the contrary, $\mathrm{Hg}^{2+}$ tends to be the principal form in the flue gases emitted from non-ferrous metal smelters, cement plants and iron and steel plants. Catalytic metallic components and high PM concentrations in flue gases are the two primary causes. Flue gas purification systems and processes in acid plants for non-ferrous metal smelting contribute to the largest amount of mercury removal in non-ferrous metal smelters. Specific mercury reclaiming tower in non-ferrous metal smelters preferentially releases $\mathrm{Hg}^{0}$ to downstream flue gases. The key to mercury emission controls in cement plants is to break the mercury cycling processes during the dust recirculation for the kiln, raw mill, and coal mill. Since $\mathrm{Hg}^{2+}$ dominates the mercury speciation of emissions from cement plants and iron and steel plants, WS or WFGD could be implemented for mercury abatement.

Mercury speciation profiles for key sources reported in recent studies are significantly different from those obtained in early studies. This is partially because the APCDs used in these sources have advanced in the past 2 decades. Another reason lies in the lack of on-site measurements in early emission estimates where certain speciation profiles were assumed. Adoption of different APCDs and use of different fuels or raw materials cause distinct differences found in mercury speciation profiles applied in different countries or regions. Large proportion of $\mathrm{Hg}^{2+}$ from non-ferrous metal smelters, cement plants and iron and steel plants calls for local attention. There are still large uncertainties in the speciation profiles at key sources, such as iron and steel plants, waste incineration, and biomass burning. More on-site measurements for these sources should be carried out to complete the database of mercury emission speciation. Research is also needed in understanding the mechanism of mercury oxidation and adsorption in flue gases with different compositions, which benefits mercury emission controls. Accurate speciation profiles improve the performance of regional transport and dispersion models to better assess the environmental impacts of mercury emissions into the atmosphere.

Acknowledgements. This work was funded by Major State Basic Research Development Program of China (973 Program) (No. 2013CB430001 and No. 2013CB430003) and National Natural Science Foundation of China (No. 21307070).

Edited by: R. Ebinghaus

\section{References}

Acuña-Caro, C., Brechtel, K., Scheffknecht, G., and Braß, M.: The effect of chlorine and oxygen concentrations on the removal of mercury at an FGD-batch reactor, Fuel, 88, 2489-2494, 2009.

Arctic Monitoring and Assessment Programme (AMAP) and United Nations Environment Programme (UNEP): Technical Background Report to the Global Atmospheric Mercury Assessment, Geneva, Switzerland, 2008.

Bhardwaj, R., Chen, X. H., and Vidic, R. D.: Impact of fly ash composition on mercury speciation in simulated flue gas, J. Air Waste Manage., 59, 1331-1338, 2009.

Bock, J., Hocquel, M. J. T., Unterberger, S., and Hein, K. R. G.: Mercury oxidation across SCR catalysts of flue gas with varying $\mathrm{HCl}$ concentrations, U.S. Environmental Protection AgencyDepartment of Energy-EPRI Combined Power Plant Air Pollutant Control Symposium, 19-20 May 2003, Washington, DC, USA, 2003.

Carpi, A.: Mercury from combustion sources: a review of the chemical species emitted and their transport in the atmosphere, Water Air Soil Pollut., 98, 241-254, 1997.

Chang, J. S. and Ghorishi, S. B.: Simulation and evaluation of elemental mercury concentration increase in flue gas across a wet scrubber, Environ. Sci. Technol., 37, 5763-5766, 2003.

Chen, J., Yuan, D., Li, Q., Zheng, J., Zhu, Y., Hua, X., He, S., and Zhou, J.: Effect of flue-gas cleaning devices on mercury emission from coal-fired boiler, P. CSEE, 28, 72-76, 2008.

Chen, L., Duan, Y., Zhuo, Y., Yang, L., Zhang, L., Yang, X., Yao, Q., Jiang, Y., and $\mathrm{Xu}, \mathrm{X}$.: Mercury transformation across particulate control devices in six power plants of China: The co-effect of chlorine and ash composition, Fuel, 86, 603-610, 2007. 
Chen, L. G., Liu, M., Fan, R. F., Ma, S. X., Xu, Z. C., Ren, M. Z., and $\mathrm{He}, \mathrm{Q}$. S.: Mercury speciation and emission from municipal solid waste incinerators in the Pearl River Delta, South China, Sci. Total Environ., 447, 396-402, 2013.

Chrystall, L. and Rumsby, A.: Mercury Inventory for New Zealand 2008, available at: http://www.mfe.govt.nz/sites/default/ files/mercury-inventory-new-zealand-2008.pdf (last access: 23 November 2015), 2009.

Duan, Y., Cao, Y., Kellie, S., Liu, K., Riley, J. T., and Pan, W.: Insitu measurement and distribution of flue gas mercury for a utility PC boiler system, J. Southeast Univ., 21, 53-57, 2005.

Dunham, G. E., Dewall, R. A., and Senior, C. L.: Fixed-bed studies of the interactions between mercury and coal combustion fly ash, Fuel Process. Technol., 82, 197-213, 2003.

Friedli, H. R., Radke, L. F., Lu, J. Y., Banic, C. M., Leaitch, W. R., and MacPherson, J. I.: Mercury emissions from burning of biomass from temperate North American forests:laboratory and airborne measurements, Atmos. Environ., 37, 253-267, 2003.

Fu, X. W., Feng, X. B., Sommar, J., and Wang, S. F.: A review of studies on atmospheric mercury in China, Sci. Total Environ., 421-422, 73-81, 2012.

Fukuda, N., Takaoka, M., Doumoto, S., Oshita, K., Morisawa, S., and Mizuno, T.: Mercury emission and behavior in primary ferrous metal production, Atmos. Environ., 45, 3685-3691, 2011.

Galbreath, K. C. and Zygarlicke, C. J.: Mercury transformations in coal combustion flue gas, Fuel Process. Technol., 65-66, 289$310,2000$.

Galbreath, K. C., Zygarlicke, C. J., Tibbetts, J. E., Schulz, R. L., and Dunham, G. E.: Effects of NOx, $\alpha-\mathrm{Fe}_{2} \mathrm{O}_{3}, \gamma-\mathrm{Fe}_{2} \mathrm{O}_{3}$, and $\mathrm{HCl}$ on mercury transformations in a $7-\mathrm{kW}$ coal combustion system, Fuel Process. Technol., 86, 429-448, 2005.

Goodarzi, F.: Speciation and mass-balance of mercury from pulverized coal fired power plants burning western Canadian subbituminous coals, J. Environ. Monit., 6, 792-798, 2004.

Guo, X., Zheng, C., Jia, X., Lin, Z., and Liu, Y.: Study on mercury speciation in pulverized coal-fired flue gas, P. CSEE, 24, 185188, 2004

Gustin, M. S., Lindberg, S. E., and Weisberg, P. J.: An update on the natural sources and sinks of atmospheric mercury, Appl. Geochem., 23, 482-493, 2008.

Hoenig, V. H. R. and Zunzer, U.: Guidance document on BAT-BEP for mercury in the cement industry, Technical report of the European Cement Research Academy (ECRA) on behalf of WBCSD Cement Sustainability Initiative, TR-ECRA 0049a/2013/M, available at: http://www.unep.org/chemicalsandwaste/Portals/9/ CSI_Hg-Report_final_10_06_13.pdf (last access: 23 November 2015), 2013.

Hu, D., Zhang, W., Chen, L., Chen, C., Ou, L. B., Tong, Y. D., Wei, W., Long, W. J., and Wang, X. J.: Mercury emissions from waste combustion in China from 2004 to 2010, Atmos. Environ., 62, 359-366, 2012.

Huang, J. Y., Hopke, P. K., Choi, H.-D., Laing, J. R., Cui, H. L., Zananski, T. J., Chandrasekaran, S. R., Rattigan, O. V., and Holsen, T. M.: Mercury (Hg) emissions from domestic biomass combustion for space heating, Chemosphere, 84, 1694-1699, 2011.

Hylander, L. D. and Herbert, R. B.: Global emission and production of mercury during the pyrometallurgical extraction of nonferrous sulfide ores, Environ. Sci. Technol., 42, 5971-5977, 2008.
Information Collection Request (ICR): Results from onsite measurements in USA, Washington, DC, USA, 2010.

Ito, S., Yokoyama, T., and Asakura, K.: Emissions of mercury and other trace elements from coal-fired power plants in Japan, Sci. Total Environ., 368, 397-402, 2006.

Kellie, S., Duan, Y., Cao, Y., Chu, P., Mehta, A., Carty, R., Liu, K., Pan, W., and Riley, J. T.: Mercury emissions from a 100MW wall-fired boiler as measured by semicontinuous mercury monitor and Ontario Hydro Method, Fuel Process. Technol., 85, 487-499, 2004.

Kilgroe, J., Sedman, C., Srivastava, R., Ryan, J., Lee, C., and Thorneloe, S.: Control of mercury emissions from coal-fired electric utility boilers: interim report including errata dated 3-21-02, EPA-600/R-01-109, EPA Office of Research and Development, National Risk Management and Research Laboratory: Research Triangle Park, NC, USA, 2002.

Kim, J. H., Park, J. M., Lee, S. B., Pudasainee, D., and Seo, Y. C.: Anthropogenic mercury emission inventory with emission factors and total emission in Korea, Atmos. Environ., 44, 27142721, 2010a.

Kim, J. H., Pudasainee, D., Yoon, Y. S., Son, S. U., and Seo, Y. C.: Studies on speciation changes and mass distribution of mercury in a bituminous coal-fired power plant by combining field data and chemical equilibrium calculation, Ind. Eng. Chem. Res., 49, 5197-5203, 2010b.

Kim, J. H., Pudasainee, D., Jung, S. J., and Seo, Y. C.: Speciation and mass balance of mercury in non-ferrous metals manufacturing facilities, The 10th International Conference on Mercury as a Global Pollutant, 24-29 July 2011, Halifax, Nova Scotia, Canada, 2011.

Krishnakumar, B. and Helble, J. J.: Understanding mercury transformations in coal-fired power plants: Evaluation of homogeneous $\mathrm{Hg}$ oxidation mechanisms, Environ. Sci. Technol., 41, 7870-7875, 2007.

Lee, C. W., Srivastava, R. K., Ghorishi, S. B., Hastings, T. W., and Stevens, F. M.: Study of speciation of mercury under simulated SCR NOx emission control conditions, U.S. Environmental Protection Agency-Department of Energy-EPRI Combined Power Plant Air Pollutant Control Symposium, 19-20 May 2003, Washington, DC, USA, 2003.

Lee, S. J., Seo, Y. C., Jang, H. N., Park, K. S., Baek, J. I., An, H. S., and Song, K. C.: Speciation and mass distribution of mercury in a bituminous coal-fired power plant, Atmos. Environ., 40, 22152224, 2006.

Li, G. H., Feng, X. B., Li, Z. G., Qiu, G. L., Shang, L. H., Liang, P., Wang, D. Y., and Yang, Y. K.: Mercury emission to atmosphere from primary Zn production in China, Sci. Total Environ., 408, 4607-4612, 2010.

Li, J.: Distribution features of mercury compounds in gold deposits, Geology and Exploration, 11, 46-51, 1990.

Lin, C. J., Shetty, S. K., Pan, L., Pongprueksa, P., Jang, C., and Chu, H. W.: Source attribution for mercury deposition in the contiguous United States: Regional difference and seasonal variation, J. Air Waste Manage., 62, 52-63, 2012.

Lindberg, S. E., Bullock, R., Ebinghaus, R., Engstrom, D., Feng, X. B., Fitzgerald, W., Pirrone, N., Prestbo, E., and Seigneur, C.: A synthesis of progress and uncertainties in attributing the sources of mercury in deposition, Ambio, 36, 19-32, 2007. 
Linero, A. A.: Synopsis of mercury controls at Florida cement plants, The 104th Annual Conference and Exhibition of the Air and Waste Management Association, 21-24 June 2011, Orlando, Florida, USA, 2011.

Liu, J., Qu, W., Yuan, J., Wang, S., Qiu, J., and Zheng, C.: Theoretical studies of properties and reactions involving mercury species present in combustion flue gases, Energ. Fuel., 24, 117122,2010

Liu, X. L., Wang, S. X., Zhang, L., Wu, Y., Duan, L., and Hao, J. M.: Speciation of mercury in FGD gypsum and mercury emission during the wallboard production in China, Fuel, 111, 621-627, 2013.

López-Antón, M. A., Díaz-Somoano, M., Abad-Valle, P., and Martínez-Tarazona, M. R.: Mercury and selenium retention in fly ashes: Influence of unburned particle content, Fuel, 86, 2064 2070, 2007.

López-Antón, M. A., Perry, R., Abad-Valle, P., Díaz-Somoano, M., Martínez-Tarazona, M. R., and Maroto-Valer, M. M.: Speciation of mercury in fly ashes by temperature programmed decomposition, Fuel Process. Technol., 92, 707-711, 2011.

Lu, Y., Rostam-Abadi, M., Chang, R., Richardson, C., and Paradis, J.: Characteristics of fly ashes from full-scale coal-fired power plants and their relationship to mercury adsorption, Energ. Fuel., 21, 2112-2120, 2007.

Machalek, T., Ramavajjala, M., Richardson, M., and Richardson, C.: Pilot evaluation of flue gas mercury reactions across an SCR unit, U.S. Environmental Protection Agency-Department of Energy-EPRI Combined Power Plant Air Pollutant Control Symposium, 19-20 May 2003, Washington, DC, USA, 2003.

Meij, R. and Winkel, H. T.: Mercury emissions from coal-fired power stations: The current state of the art in the Netherlands, Sci. Total Environ., 368, 393-396, 2006.

Mlakar, T. L., Horvat, M., Vuk, T., Stergaršek, A., Kotnik, J., Tratnik, J., and Fajon, V.: Mercury species, mass flows and processes in a cement plant, Fuel, 89, 1936-1945, 2010.

Nelson, P. F., Morrison, A. L., Malfroy, H. J., Cope, M., Lee, S., Hibberd, M. L., Meyer, C. P., and McGregor, J.: Atmospheric mercury emissions in Australia from anthropogenic, natural and recycled sources, Atmos. Environ., 62, 291-302, 2012.

Niksa, S. and Fujiwara, N.: A predictive mechanism for mercury oxidation on selective catalytic reduction catalysts under coalderived flue gas, J. Air Waste Manage., 55, 1866-1875, 2005.

Niksa, S., Helble, J. J., and Fujiwara, N.: Kinetic modeling of homogeneous mercury oxidation: The importance of $\mathrm{NO}$ and $\mathrm{H}_{2} \mathrm{O}$ in predicting oxidation in coal-derived systems, Environ. Sci. Technol., 35, 3701-3706, 2001.

Norton, G. A., Yang, H., Brown, R. C., Laudal, D. L., Dunham, D. E., and Erjavec, J.: Heterogeneous oxidation of mercury in simulated post combustion conditions, Fuel, 82, 107-116, 2003.

Ochoa-González, R., Díaz-Somoano, M., López-Antón, M. A., and Martínez-Tarazona, M. R.: Effect of adding aluminum salts to wet FGD systems upon the stabilization of mercury, Fuel, 96, 568-571, 2012.

Ochoa-González, R., Díaz-Somoano, M., and Martínez-Tarazona, M. R.: Influence of limestone characteristics on mercury reemission in WFGD systems, Environ. Sci. Technol., 47, 2974 2981, 2013.
Omine, N., Romero, C. E., Kikkawa, H., Wu, S., and Eswaran, S.: Study of elemental mercury re-emission in a simulated wet scrubber, Fuel, 91, 93-101, 2012.

Pacyna, E. G. and Pacyna, J. M.: Global emission of mercury from anthropogenic sources in 1995, Water Air Soil Pollut., 137, 149$165,2002$.

Pacyna, E. G., Pacyna, J. M., Steenhuisen, F., and Wilson, S.: Global anthropogenic mercury emission inventory for 2000, Atmos. Environ., 22, 4048-4063, 2006.

Pacyna, J. M. and Münch, J.: Anthropogenic mercury emission in Europe, Water Air Soil Pollut., 56, 51-61, 1991.

Paone, P.: Mercury controls for the cement industry, Cement Industry Technical Conference, 28 March-1 April 2010, Colorado Springs, Colorado, USA, 2010.

Park, K. S., Seo, Y. C., Lee, S. J., and Lee, J. H.: Emission and speciation of mercury from various combustion sources, Powder Technol., 180, 151-156, 2008.

Rallo, M., López-Antón, M. A., Perry, R., and Maroto-Valer, M. M.: Mercury speciation in gypsums produced from flue gas desulfurization by temperature programmed decomposition, Fuel, 89, 2157-2159, 2010.

Ren, W., Duan, L., Zhu, Z. W., Du, W., An, Z. Y., Xu, L. J., Zhang, C., Zhuo, Y. Q., and Chen, C. H.: Mercury transformation and distribution across a polyvinyl chloride (PVC) production line in China, Environ. Sci. Technol., 48, 2321-2327, 2014.

Rutter, A. P. and Schauer, J. J.: The effect of temperature on the gas - particle partitioning of reactive mercury in atmospheric aerosols, Atmos. Environ., 41, 8647-8657, 2007.

Schreiber, R. J., Kellet, C. D., Joshi, N., and Skokie, I. L.: Inherent mercury controls within the Portland cement kiln system, Portland Cement Association, Skokie, IL, USA, 2005.

Schroeder, W. H. and Munthe, J.: Atmospheric mercury - An overview, Atmos. Environ., 32, 809-822, 1998.

Schuetze, J., Kunth, D., Weissbach, S., and Koeser, H.: Mercury vapor pressure of flue gas desulfurization scrubber suspensions: effects of the $\mathrm{pH}$ level, gypsum and iron, Environ. Sci. Technol., 46, 3008-3013, 2012.

Senior, C. and Johnson, S.: Impact of carbon-in-ash on mercury removal across particulate control devices in coal-fired power plants, Energ. Fuel., 19, 859-863, 2005.

Senior, C., Montgomery, C. J., and Sarofim, A.: Transient model for behavior of mercury in Portland cement kilns, Ind. Eng. Chem. Res., 49, 1436-1443, 2010.

Senior, C. L., Sarofim, A. F., Zeng, T., Helble, J. J., and MamaniPaco, R.: Gas-phase transformations of mercury in coal-fired power plants, Fuel Process. Technol., 63, 197-213, 2000.

Shah, P., Strezov, V., Prince, K., and Nelson, P. F.: Speciation of As, $\mathrm{Cr}$, Se and $\mathrm{Hg}$ under coal fired power station conditions, Fuel, 87, 1859-1869, 2008.

Shah, P., Strezov, V., and Nelson, P.: Speciation of mercury in coalfired power station flue gas, Energ. Fuel., 24, 205-212, 2010.

Sikkema, J. K., Alleman, J. E., Ong, S. K., and Wheelock, T. D.: Mercury regulation, fate, transport, transformation, and abatement within cement manufacturing facilities: review, Sci. Total Environ., 409, 4167-4178, 2011.

Song, J. X.: Study on atmospheric mercury emissions from typical zinc smelting process, MS thesis, Tsinghua University, Beijing, China, 2010. 
Sterling, R. O., Qiu, J. R., and Helble, J. J.: Experimental study of mercury homogeneous reaction chemistry under post-flame conditions, The 227th Spring ACS National Meeting, 28 March1 April 2004, Anaheim, CA, USA, 2004.

Streets, D. G., Hao, J. M., Wu, Y., Jiang, J. K., Chan, M., Tian, H. Z., and Feng, X. B.: Anthropogenic mercury emissions in China, Atmos. Environ., 39, 7789-7806, 2005.

Takahashi, F., Shimaoka, T., and Kida, A.: Atmospheric mercury emissions from waste combustions measured by continuous monitoring devices, J. Air Waste Manage., 62, 686-695, 2012.

Takaoka, M., Oshita, K., Takeda, N., and Morisawa, S.: Mercury emission from crematories in Japan, Atmos. Chem. Phys., 10, 3665-3671, doi:10.5194/acp-10-3665-2010, 2010.

Tang, S.: The mercury species and emissions from coal combustion flue gas and landfill gas in Guiyang, $\mathrm{PhD}$ thesis, Institute of Geochemistry, Chinese Academy of Sciences, Guiyang, China, 2004.

Tang, S. L., Feng, X. B., Qiu, J. R., Yin, G. X., and Yang, Z. C.: Mercury speciation and emissions from coal combustion in Guiyang, southwest China, Environ. Res., 105, 175-182, 2007.

United Nations Economic Commission for Europe (UNECE): Guidance document on best available techniques for controlling emissions of heavy metals and their compounds from the source categories listed in annex II to the Protocol on Heavy Metals, Geneva, Switzerland, 2013.

United Nations Environment Programme (UNEP): Global Mercury Assessment 2013: Sources, Emissions, Releases and Environmental Transport, Geneva, Switzerland, 2013a.

United Nations Environment Programme (UNEP): Minamata Convention on Mercury, available at: http://www. mercuryconvention.org/Convention/tabid/3426/Default.aspx (last access: 1 February 2016), 2013b.

Verein deutscher Zementwerke e.V. (VDZ): Activity Report 19992001, Düsseldorf, Germany, 2002.

Walcek, C., de Santis, S., and Gentile, T.: Preparation of mercury emissions inventory for eastern North America, Environ. Pollut., 123, 375-381, 2003.

Wang, F. Y., Wang, S. X., Zhang, L., Yang, H., Wu, Q. R., and Hao, J. M.: Mercury enrichment and its effects on atmospheric emissions in cement plants of China, Atmos. Environ., 92, 421-428, 2014.

Wang, F. Y., Wang, S. X., Meng, Y., Zhang, L., Wu, Q. R., and Hao, J. M.: Mechanisms and roles of fly ash compositions on the adsorption and oxidation of mercury in flue gas from coal combustion, Fuel, 163, 232-239, 2016 a.

Wang, F. Y., Wang, S. X., Zhang, L., Yang, H., Gao, W., Wu, Q. R., and Hao, J. M.: Mercury mass flow in iron and steel production process and its implications for mercury emission control, J. Environ. Sci., doi:10.1016/j.jes.2015.07.019, 2016 b.

Wang, L., Wang, S. X., Zhang, L., Wang, Y. X., Zhang, Y. X., Nielsen, C., McElroy, M. B., and Hao, J. M.: Source apportionment of atmospheric mercury pollution in China using the GEOS-Chem model, Environ. Pollut., 190, 166-175, 2014.

Wang, Q. W.: New technology for treatment of mercury-containing acidic wastewater from gas washing process in lead and zinc smelting by biologics, PhD thesis, Central South University, Changsha, China, 2011.

Wang, S. X., Zhang, L., Li, G. H., Wu, Y., Hao, J. M., Pirrone, N., Sprovieri, F., and Ancora, M. P.: Mercury emission and speci- ation of coal-fired power plants in China, Atmos. Chem. Phys. 10, 1183-1192, doi:10.5194/acp-10-1183-2010, 2010a.

Wang, S. X., Song, J. X., Li, G. H., Wu, Y., Zhang, L., Wan, Q., Streets, D. G., and Chin, C. K.: Estimating mercury emissions from a zinc smelter in relation to China's mercury control policies, Environ. Pollut., 158, 3347-3353, 2010b.

Wang, S. X., Zhang, L., Hao, J. M., Chen, J. B., Li, Z. G., Yan, N. Q., and Qu, Z.: Mid-term Report for Emission Inventory and Isotopic Characteristics of Mercury from Anthropogenic Sources in China, Mid-term Seminar for 973 Project "The Pollution Characteristics, Environmental Processes and Emission Control Principle of Mercury in China”, Guiyang, China, 2014.

Wang, Y., Duan, Y., Yang, L., and Jiang, Y.: An analysis of the factors exercising an influence on the morphological transformation of mercury in the flue gas of a $600 \mathrm{MW}$ coal-fired power plant, J. Eng. Therm. Energ. Power, 23, 399-403, 2008.

Wang, Y., Duan, Y., Yang, L., Zhao, C., Shen, X., Zhang, M., Zhuo, Y., and Chen, C.: Experimental study on mercury transformation and removal in coal-fired boiler flue gases, Fuel Process. Technol., 90, 643-651, 2009.

Wei, W.: Emission of mercury from biomass fuels burning in rural China, MS thesis, Peking University, Beijing, China, 2012.

Widmer, N. C., West, J., and Cole, J. A.: Thermochemical study of mercury oxidation in utility boiler flue gases, The 93rd Air and Waste Management Association Annual Meeting, 18-22 June 2000, Salt Lake City, UT, USA, 2000.

Wilcox, J., Robles, J., Marsden, D. C. J., and Blowers, P.: Theoretically predicted rate constants for mercury oxidation by hydrogen chloride in coal combustion flue gases, Environ. Sci. Technol., 37, 4199-4204, 2003.

Winberg, S., Winthum, J., Tseng, S., and Locke, J.: Evaluation of mercury emissions from coal-fired facilities with SCR-FGD systems, DOE/NETL Mercury Control Technology R\&D Program Review, Pittsburgh, PA, USA, 2004.

Wo, J., Zhang, M., Cheng, X., Zhong, X., Xu, J., and Xu, X.: Hg2+ reduction and re-emission from simulated wet flue gas desulfurization liquors, J. Hazard. Mater., 172, 1106-1110, 2009.

Won, J. H. and Lee, T. G.: Estimation of total annual mercury emissions from cement manufacturing facilities in Korea, Atmos. Environ., 62, 265-271, 2012.

Wu, Q. R., Wang, S. X., Zhang, L., Song, J. X., Yang, H., and Meng, Y.: Update of mercury emissions from China's primary zinc, lead and copper smelters, 2000-2010, Atmos. Chem. Phys., 12, 11153-11163, doi:10.5194/acp-12-11153-2012, 2012.

Wu, Q. R., Wang, S. X., Hui, M. L., Wang, F. Y., Zhang, L., Duan, L., and Luo, Y.: New insight into atmospheric mercury emissions from zinc smelters using mass flow analysis, Environ. Sci. Technol., 49, 3532-3539, 2015.

Wu, Y., Wang, S. X., Streets, D. G., Hao, J. M., Chan, M., and Jiang, J. K.: Trends in anthropogenic mercury emissions in China from 1995 to 2003, Environ. Sci. Technol., 40, 5312-5318, 2006.

Yang, M.: Research on atmospheric mercury emission inventory and control technology of gold production in China, Postdoctoral work report, Tsinghua University, Beijing, China, 2015.

Yang, X., Duan, Y., Jiang, Y., and Yang, L.: Research on mercury form distribution in flue gas and fly ash of coal-fired boiler, Coal Sci. Technol., 35, 55-58, 2007. 
Yokoyama, T., Asakura, K., Matsuda, H., Ito, S., and Noda, N.: Mercury emissions from a coal-fired power plant in Japan, Sci. Total Environ., 259, 97-103, 2000.

Zhang, H., He, P. J., and Shao, L. M.: Fate of heavy metals during municipal solid waste incineration in Shanghai, J. Hazard. Mater., 156, 365-373, 2008.

Zhang, L.: Emission characteristics and synergistic control strategies of atmospheric mercury from coal combustion in China, PhD thesis, Tsinghua University, Beijing, China, 2012.

Zhang, L., Wang, S. X., Meng, Y., and Hao, J. M.: Influence of mercury and chlorine content of coal on mercury emissions from coal-fired power plants in China, Environ. Sci. Technol., 46, 6385-6392, 2012a.

Zhang, L., Wang, S. X., Wu, Q. R., Meng, Y., Yang, H., Wang, F. Y., and Hao, J. M.: Were mercury emission factors for Chinese non-ferrous metal smelters overestimated? Evidence from onsite measurements in six smelters, Environ. Pollut., 171, 109-117, 2012b.

Zhang, L., Daukoru, M., Torkamani, S., Wang, S. X., Hao, J. M., and Biswas, P.: Measurements of mercury speciation and fine particle size distribution on combustion of China coal seams, Fuel, 104, 732-738, 2013a.
Zhang, L., Wang, S. X., Wang, F. Y., Yang, H., Wu, Q. R., and Hao, J. M.: Mercury transformation and removal in three coal-fired power plants with selective catalytic reduction systems, The 11th International Conference on Mercury as a Global Pollutant, 28 July-2 August 2013, Edinburgh, Scotland, UK, 2013 b.

Zhang, L., Wang, S. X., Wang, L., Wu, Y., Duan, L., Wu, Q. R., Wang, F. Y., Yang, M., Yang, H., Hao, J. M., and Liu, X.: Updated emission inventories for speciated atmospheric mercury from anthropogenic sources in China, Environ. Sci. Technol., 49, 3185-3194, 2015.

Zhang, W., Wei, W., Hu, D., Zhu, Y., and Wang, X. J.: Emission of speciated mercury from residential biomass fuel combustion in China, Energ. Fuel., 27, 6792-6800, 2013.

Zheng, Y., Jensen, A. D., Windelin, C., and Jensen, F.: Review of technologies for mercury removal from flue gas from cement production processes, Prog. Energ. Combust. Sci., 38, 599-629, 2012.

Zhou, J., Wang, G., Luo, Z., and Cen, K.: An experimental study of mercury emissions from a $600 \mathrm{MW}$ pulverized coal-fired boiler, J. Eng. Therm. Energ. Power, 21, 569-572, 2006.

Zhou, J., Zhang, L., Luo, Z., and Hu, C.: Study on mercury emission and its control for boiler of $300 \mathrm{MW}$ unit, Therm. Power Gener., 37, 22-27, 2008. 